\title{
17. LATE PLIOCENE (2.9 MA) PARTIAL RECOVERY OF SHALLOW CARBONATE BANKS ON THE QUEENSLAND PLATEAU: SIGNAL OF BANK-TOP REENTRY INTO THE PHOTIC ZONE DURING A LOWERING IN SEA LEVEL ${ }^{1}$
}

\author{
André W. Droxler, ${ }^{2}$ Geoffrey A. Haddad, ${ }^{2}$ Dick Kroon, ${ }^{3}$ Stefan Gartner, ${ }^{4}$ Wuchang Wei, ${ }^{5}$ and Donald McNeill ${ }^{6}$
}

\begin{abstract}
Shedding of shallow carbonate material toward the deep slopes and basin floors is clearly tied to the position of the carbonate bank tops relative to the photic zone. The onset of bank shedding in periplatform sediments can record either the flooding of the bank tops within the photic zone during a rise in sea level following a period of exposure, referred to in the literature as the "highstand shedding" scenario, or the reentry of the bank tops into the photic zone during a lowering of sea level following a period of drowning, referred to as the "lowstand shedding" scenario. Results from Leg 133 post-cruise research on the Pliocene sequences, drilled in six sites within different slope settings of the Queensland Plateau, seem to point out that the latter "lowstand shedding" scenario can be applied to this particular carbonate system.

At the Queensland Plateau sites, the early Pliocene (5.2-3.5 Ma) and the earliest part of the late Pliocene (3.5-2.9 Ma) age sequences were characterized, especially in the "deep" Sites 811 and 817 , by pelagic sediments (foraminifers and coccoliths) and by typically pelagic sedimentation rates not exceeding $20 \mathrm{~mm} / \mathrm{k} . \mathrm{y}$. The earliest part of the late Pliocene age section was characterized by well-developed hardgrounds in the "shallow" Sites 812 and 814 and by normal pelagic sediments mixed with reworked phosphatized planktonic foraminifers in Site 813. Finally, the early part of the late Pliocene (2.9-2.4 Ma) section was characterized by high sedimentation rates, related to the shedding and admixture into the pelagic sediments of bank-derived materials. These bank-derived materials consist of either diagenetically unaltered fine aragonite with traces of dolomite in Site 818 or micritic calcite resulting from seafloor and/or shallow burial alteration in the deepest Sites 817 and 811 . The highest sedimentation rates $(163 \mathrm{~mm} / \mathrm{k} . \mathrm{y}$.) were recorded in Site 818, drilled nearest the modern carbonate bank of Tregrosse Reef. The sedimentation rates decrease with increasing distance from Tregrosse Reef $-120 \mathrm{~mm} / \mathrm{k} . \mathrm{y}$. in Site 817 and $47.5 \mathrm{~mm} / \mathrm{k} . \mathrm{y}$. in Site 811. The initial appearance of fine aragonite in Site 818, corresponding to the transition from pelagic to periplatform sedimentation rates, has been dated at $2.9 \mathrm{Ma}$. This Pliocene sediment pattern on the Queensland Plateau is different from the pattern observed in sediments from two earlier ODP legs (i.e., Leg 101 in the Bahamas and in Leg 115 in the Maldives), where aragonite-rich sediments, characterized by high periplatform sedimentation rates, were observed in the lower Pliocene section (5.2-3.5 Ma), whereas the upper Pliocene (3.5-1.6 Ma) sediments are more pelagic in nature and are characterized by low sedimentation rates or major hiatuses. These Pliocene periplatform sequences in the Bahamas and in the Maldives and late Quaternary age periplatform sequences worldwide have pointed out that "highstand shedding" was the typical response of carbonate platforms to fluctuations in sea level, just opposite to a "lowstand shedding" response to sea-level fluctuations, typical of siliciclastic shelves.

Assuming that the envelope of Haq et al.'s (1987) sea-level curve, showing a well-defined lowering of sea level between 3.5 and $2.9 \mathrm{Ma}$, can also be applied to the southwest Pacific Ocean, based on a high-resolution Pliocene $\delta^{18} \mathrm{O}$ record from the Ontong Java Plateau recently published by Jansen et al. (in press), the Pliocene periplatform sequences on the Queensland Plateau would have recorded the reentry of the bank tops into the photic zone during a general lowering of sea level, following an interval characterized by high sea level, during which the shallow carbonate system on the Queensland Plateau was drowned. The early Pliocene age (5.2-3.5 Ma) sediments deposited on the Queensland Plateau, an established interval of eustatic sea-level highstand, are typically pelagic in character. In addition, relatively cold surface temperatures (estimated to have ranged from $18^{\circ}$ to $20^{\circ} \mathrm{C}$ by Isern et al. [this volume]) might have also stressed the reefs during early Pliocene time and contributed to the drowning of the Queensland Plateau carbonate system during the late Miocene and early Pliocene. Differential and relatively high subsidence rates, inferred by variations in paleodepth of water (based upon benthic foraminifer assemblages; Katz and Miller, this volume) may also have influenced the drowning of the carbonate bank tops on the Queensland Plateau during the late Miocene and early Pliocene. The sediments of early late Pliocene age (2.9-2.4 Ma), a well-established interval of lowering of sea level, are clearly periplatform and cyclic in nature. High-frequency $(\sim 40 \mathrm{k} . y$.) aragonite cycles, well-developed between 2.9 and $2.45 \mathrm{Ma}$, correlate with the planktonic high-resolution Pliocene $\delta^{18} \mathrm{O}$ record from the Ontong Java Plateau, a good sea-level proxy (Jansen et al., in press). Contrary to late Quaternary age aragonite cycles from the Bahamas, the Nicaragua Rise, the Maldives, and the Queensland Plateau, the late Pliocene aragonite cycles in Hole 818B display high levels of aragonite during glacial stages and, therefore, lowstands of sea level. In addition, sediments deposited during the earliest part of the late Pliocene (3.5-2.9 Ma), transition between the early Pliocene highstand and the late Pliocene lowering in sea level, have recorded the first evidence of a fall in sea level, by (1) the occurrence of synchronous submarine hardgrounds in the two shallowest sites (Sites 812 and 814), (2) the deposition of reworked material from the shallower part of the slope into the intermediate Sites 813 and 818, and (3) the deposition of pelagic sediments in the deepest Sites 817 and 817. In summary, contrary to previous findings, the Pliocene periplatform sediments on the Queensland Plateau appear to have recorded a regional shedding of shallow carbonate bank tops during an interval of sea-level lowering, a good illustration of the "carbonate lowstand shedding" scenario, occurring during the reentry of previously drowned carbonate bank tops into the photic zone related to a decrease in sea level.
\end{abstract}

\footnotetext{
${ }^{1}$ McKenzie, J.A., Davies, P.J., Palmer-Julson, A., et al., 1993. Proc. ODP, Sci. Results, 133: College Station, TX (Ocean Drilling Program).

${ }^{2}$ Department of Geology and Geophysics, Rice University, P.O. Box 1892, Houston, TX 77251, U.S.A.

${ }^{3}$ Grant Institute of Geology, University of Edinburgh, West Mains Road, Edinburgh EH9 3I, U.K.

${ }_{5}^{4}$ Department of Oceanography, Texas A\&M University, College Station, TX 77843, U.S.A.

${ }^{5}$ Geology Division, Scripps Institution of Oceanography, La Jolla, CA 92093-0215, U.S.A

${ }^{6}$ Division of Marine Geology and Geophysics, Rosenstiel School of Marine and Atmospheric Sciences, University of Miami, 4600 Rickenbacker Causeway, Miami, FL 33149-1098, U.S.A.
} 


\section{INTRODUCTION}

Recent studies show that late Quaternary and Pliocene age periplatform sediments, deposited in the deep surroundings of shallow carbonate banks, have systematically recorded exposure and flooding of shallow bank tops and thus are thought to be faithful recorders of changes in sea level. In addition, because periplatform sediments, as open-marine carbonate sediments, are good proxies through time of carbonate pelagic production and water-column chemistry, their records can be tied to a more global reference framework than just the evolution of a specific bank.

Several studies of late Quaternary age periplatform sediments (mostly in the Bahamas, but also on the Nicaragua Rise and in the Maldives) have demonstrated, using Bard et al.'s (1990) well-established last 150-k.y. sea-level curve, that these sediments can be considered as a good proxy of sea-level variations (Fig. 1A). Intervals of bank-top flooding or interglacial stages correspond to a large export of bank-derived aragonite and magnesian calcite-rich sediments toward the basins. Wedges of muddy sediments, well-developed on the upper slopes adjacent to the bank edges, correspond to interglacial stages and are referred to as "highstand wedges" (Wilber et al., 1990; Glaser and Droxler, 1991). In addition, interglacial sediments in the basins generally consist of large proportions of bank-derived, fine aragonite- and Mg-calcite-rich sediments (Droxler et al., 1983; Boardman and Neumann, 1984; Boardman et al., 1986) and numerous calciturbidite layers (Droxler and Schlager, 1985), characterized by a high ratio of nonskeletal vs. skeletal grains (Haak and Schlager, 1989). In contrast, intervals of bank exposure during glacial stages correspond to a minimum export of sediments from the bank tops to their adjacent slopes and basin floors. These intervals are usually characterized on the upper slopes by hardgrounds or condensed sections (Glaser and Droxler, 1991) and in the basins by calcite-rich sediments, more
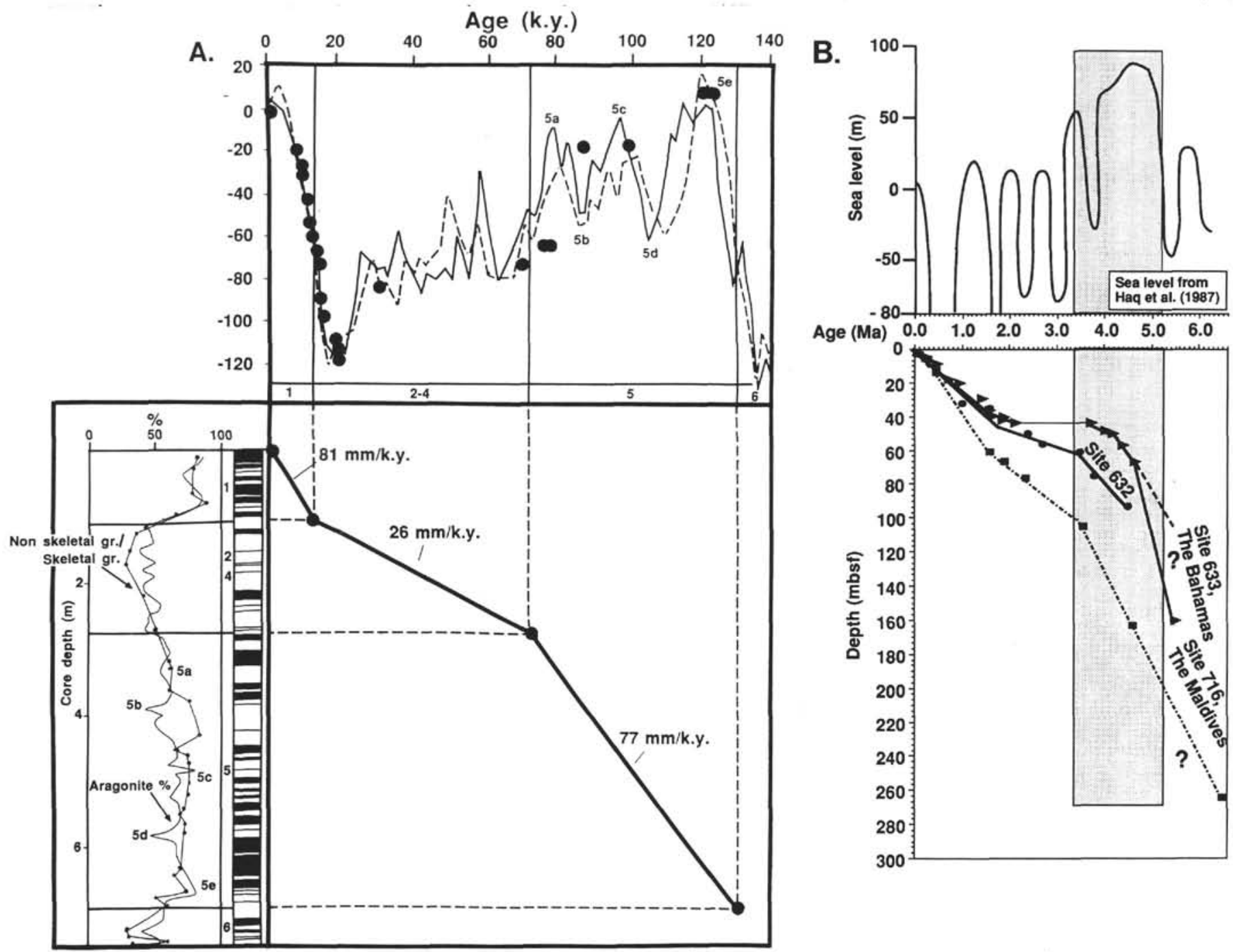

Figure 1. A. An illustration of the "highstand shedding" concept during the late Quaternary in the pure carbonate system of the Bahamas. Sea-level curves established by Bard et al. (1990) (solid dots), Shackleton (1987) (solid line), and Labeyrie et al. (1987) (dashed line) are compared with a curve showing the downcore variations of fine aragonite content (Droxler and Schlager, 1985) and grain composition in turbidite layers in periplatform sediments (Haak and Schlager, 1989) from the Tongue of the Ocean (curves on lower left). Highstands of sea level during interglacial stages 1 and 5 correspond to high sedimentation rates, high aragonite values, high frequency of turbidite layers, and high values of the ratio between non-skeletal and skeletal grains in the turbidite layers. B. The "highstand shedding" concept in the pure carbonate systems of the Bahamas and the Maldives for the past 6 m.y. illustrated by correlating the Haq et al. (1987) sea-level curve and results from periplatform sites drilled during ODP Leg 101 in the Bahamas (Sites 632 and 633) and ODP Leg 115 (Site 716) in the Maldives. Highstands of sea level during the early Pliocene and Pleistocene correspond to intervals of high sedimentation rates and aragonite-rich sediment in both areas. 
pelagic in character and in terms of sedimentation rates, with rare turbidite layers (Droxler and Schlager, 1985) that are characterized by low ratio of nonskeletal vs. skeletal grains (Haak and Schlager, 1989) (Fig. 1A). These findings have been summarized into the simple concept of "highstand shedding" for carbonate banks, in contrast to the "lowstand shedding" model for siliciclastic shelves to explain the thick basinal siliciclastic sediments deposited during glacial stages.

Furthermore, carbonate highstand shedding was also observed on a longer time scale in Pliocene-Pleistocene periplatform sequences drilled in the Bahamas and the Maldives during ODP Legs 101 and 115 (Austin, Schlager et al., 1988; Droxler et al., 1988 and 1990). Early Pliocene, an interval of particularly high eustatic sea level (Haq et al., 1987; Raymo et al., 1986; Jansen et al., in press; Hodell and Venz, 1992; Hodell and Kennett, 1986), that corresponded to a warmer climatic interval between 5.2 and $3.7 \mathrm{Ma}$ than that during the late Pliocene and Quaternary, is characterized by higher sedimentation rates (Fig. 1B) and aragonite-rich sediments in Site 633 (Exuma Sound, Bahamas, Droxler et al., 1988) and in Site 716 (Inner Sea, the Maldives, Droxler et al., 1990). In contrast, periplatform sediments deposited during the late Pliocene (3.5-1.6 Ma), an interval characterized by lower sea level and colder climate than during the early Pliocene (Haq et al., 1987; Raymo et al., 1986; Hodell and Venz, 1992; Jansen et al., in press), are characterized by a low content or absence of bank-derived aragonite and generally low sedimentation rates (Droxler et al., 1988, 1990). In summary, results from several late Quaternary and Pliocene-Pleistocene periplatform studies showed that sediments deposited in the vicinity of carbonate banks faithfully recorded fluctuations in sea level and demonstrated that "highstand shedding" is a common response of carbonate banks to fluctuations in sea level.

However, it is important to remember that shedding of bank-derived sediments into surrounding slopes and basins is primarily related

\section{SCENARIO 1: HIGHSTAND SHEDDING Increase of sedimentation rates in the basins, once the banktops, after being exposed, are flooded within the photic zone during an interval of rising sea level.}

\section{1) LOWSTAND}

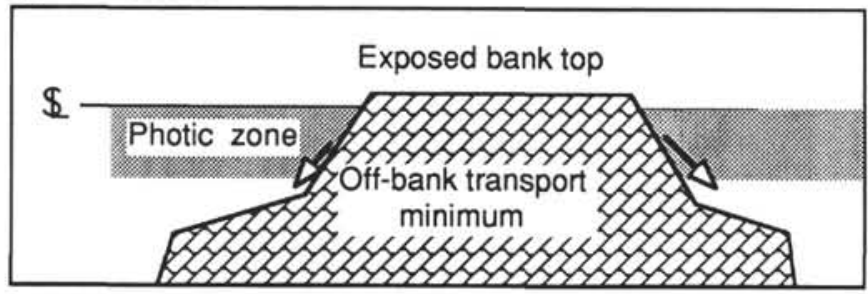

2) SEA-LEVEL RISING / HIGHSTAND RE-ENTRY OF BANKTOP INTO PHOTIC ZONE

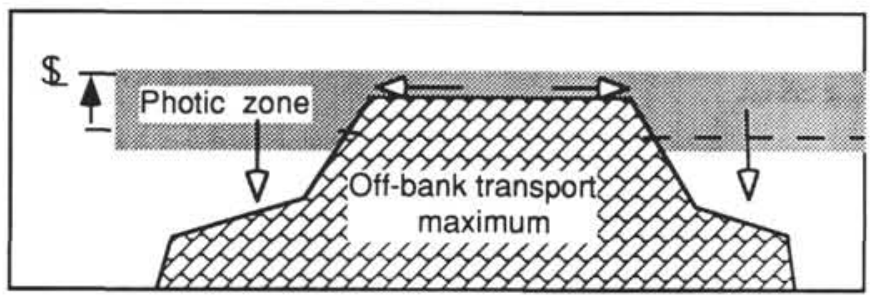

to bank-top production itself and thus is directly tied to intervals when bank tops are flooded within the photic zone. Carbonate platforms are known to have "drowned" or "demised" during intervals when sediment production ceases on bank tops flooded below the photic zone (Schlager, 1981). One would expect these intervals to be strongly recorded by the absence of bank-derived material in sediments deposited on the slopes and basins adjacent to drowned banks. The nature of sediments deposited around partially or completely drowned platforms and their accumulation rates would be expected to become pelagic and to resemble sediments deposited in the vicinity of exposed banks. The onset of a bank-derived component and a systematic increase in sedimentation rates within sedimentary sequences deposited in the vicinity of carbonate banks could correspond, either to the rapid flooding of a platform top (originally exposed) during a transgression of sea level or to the reentry of a platform top (originally drowned) into the photic zone during a regression of sea level (Fig. 2). The former "highstand shedding" scenario was systematically and clearly illustrated (as mentioned previously) in several late Quaternary studies in the Bahamas and the Maldives and on the Nicaragua Rise and the Queensland Plateau, as well as in two different studies of Pliocene-Pleistocene sequences in the Bahamas and the Maldives (see above and Figs. 1A and (B). The latter "lowstand shedding" scenario appeared to be illustrated for the first time in the results of the shipboard and post-cruise studies of six Pliocene periplatform sequences cored during Leg 133 on the Queensland Plateau and is the main topic of this study.

Here, the six periplatform sequences cored on the Queensland Plateau (ODP Sites 811, 812, 813, 814, 817, and 818) first are placed into the geographical context and the geological pre-Pliocene evolution of the Queensland Plateau. Next, age/depth curves of three sites, established on shipboard and post-cruise improved biostratigraphies (calcareous nannofossil, planktonic foraminifer) and magnetostratig-

\section{1) HIGHSTAND}

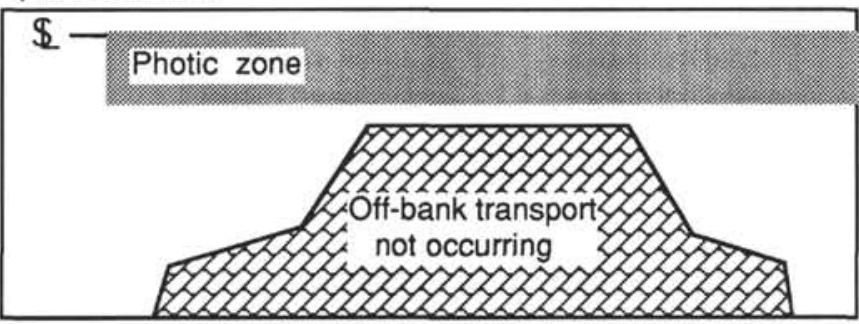

2) SEA-LEVEL FALLING / LOWSTAND RE-ENTRY OF BANKTOP INTO PHOTIC ZONE

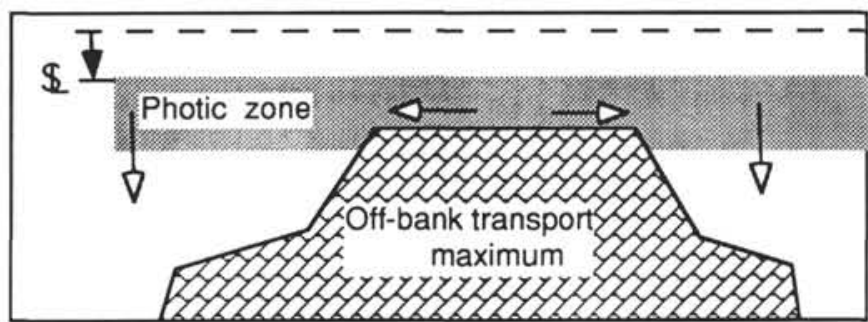

Figure 2. Comparison of (1) the most common scenario of "highstand shedding," which is based on case studies observed in the late Quaternary and the Pliocene/Pleistocene periplatform sediments of the Bahamas, the Maldives, and the Nicaragua Rise and (2) the "lowstand shedding" scenario proposed in this study to explain the Pliocene periplatform record on the Queensland Plateau. 
raphy, illustrate a systematic, unexpected, Pliocene sedimentation-rate pattern. This pattern, correlated to the shipboard lithologic descriptions of the three deepest Pliocene sequences, has been interpreted to correspond to the "lowstand shedding" scenario, which illustrates the reentry of previously drowned bank tops into the photic zone tied to a general decrease in sea level, and thus is distinctly different from the clear Pliocene "highstand shedding" pattern established in the Bahamas and the Maldives. Results of detailed lithologic, mineralogical, and isotopic post-cruise analyses support and strengthen our shipboard interpretation that the carbonate system on the Queensland Plateau was drowned during the early Pliocene eustatic highstand of sea level and recovered when sea level fell during the early part of the late Pliocene. The recovery of the carbonate system on the Queensland Plateau was only partial relative to the much larger extension of the shallow carbonate system during the middle Miocene (Fig. 3C). The Pliocene evolution of the carbonate system on the Queensland Plateau, therefore, is unique and may be the first illustration of a convincing case for "lowstand shedding" corresponding to an interval of sea-level lowering.

\section{GEOGRAPHICAL AND GEOLOGICAL SETTING OF THE QUEENSLAND PLATEAU}

\section{Geographical Setting of the Queensland Plateau}

The Queensland Plateau is limited on its northern and western sides by the Coral Sea, on its western side by the Queensland Trough, and on its southern side by the Townsville Trough (Fig. 3A). This plateau, which has a surface area of almost $160,000 \mathrm{~km}^{2}$, is approximately the same size as the Bahama Platform. Currently, one-half of the plateau is located within the $1000-\mathrm{m}$ isobath and $10 \%$ to $15 \%$ of the plateau is covered by living coral reefs, which include Tregrosse and Lihou reefs, the two largest modern reef complexes, $100 \mathrm{~km}$ long and 25 to $50 \mathrm{~m}$ wide, and smaller complexes such as Coringa Bank, Diane Bank, Willis Islets, and Flinders and Holmes reefs (Fig. 3B).

Six Pliocene sequences were recovered in the sites drilled on the Queensland Plateau during Leg 133 (Fig. 3A). Location (latitude and longitude) and water depth for each of the six sites are also listed in Figure 4. Five sites $(812,813,814,817$, and 818$)$ were drilled along the southern margin of the Queensland Plateau, west of the modern complexes of Tregrosse Reef and Coringa Bank and east of the Flinders Reefs. The sixth site (811) was drilled in the northwestern corner of the Queensland Plateau, east of Holmes Reef.

\section{Pre-Pliocene Geological Evolution of the Queensland Plateau}

Results from shipboard studies and preliminary post-cruise research indicate that carbonate sedimentation on the Queensland Plateau was initiated during the early middle Eocene, when the sea transgressed on top of the Queensland Plateau continental basement, consisting of low grade metasediments and drilled in Sites 824 and 825 (Feary et al., this volume). The initial carbonate system, established during the Oligocene, included only temperate faunas (bioclastic grainstones and rudstones, mostly bryozoans, larger foraminifers, and coralline algae) and has been interpreted to represent a temperate to subtropical shelf (Betzler et al., this volume). By the latest early Miocene, the carbonate system was dominated by tropical carbonates (drilled in Sites 811, 812, 813, and 814) that consisted of skeletal packstone and wackestone to rudstone/floatstone with coralline algae, corals, mollusks, large benthic foraminifers, and to a lesser extent, echinoderms, bryozoans, and the green algae Halimeda (Betzler et al., this volume). The established transition from temperate to tropical climates along the Australian coast during the Cenozoic (i.e., Feary et al., 1991; Betzler et al., this volume) reflected the northward movement of the Australian Plate into lower latitudes, which resulted also with the onset of oceanic surface currents from the equatorial region into tropical latitudes. During the late early and early middle Miocene (based on seismic data and drilling results), reefs were widespread on the Queensland Plateau. The carbonate banks are thought to have covered at that time the surface area contained within the present $500-\mathrm{m}$ isobath (see Fig. 3C). The tops of the carbonate banks on the Queensland Plateau became exposed at the end of the middle Miocene as a result of a major lowering in sea level. The amplitude of this fall has been estimated as approximately $87 \mathrm{~m}$ by Betzler et al. (this volume).

After being exposed at the end of the middle Miocene, the carbonate bank tops were rapidly flooded and apparently already drowned sometime during the late Miocene due to several pulses of rapid subsidence during the late Miocene and the early Pliocene, observed along the northeast Australia margin (Symonds and Davies, 1988; Katz and Miller, this volume and Fig. 5). Katz and Miller (this volume) have estimated paleodepth variations for the last 14 m.y. based on assemblages of benthic foraminifers for five out of the six sites included in this study. Their results can be used as a proxy for subsidence rates. The two deepest sites ( 811 and 817 ) display fairly constant and rapid subsidence rates in the past 14 m.y. Sites 813 and 814 from the southern edge of the Queensland Plateau, display diachronous onset of rapid subsidence rates during the late Miocene and the latest Miocene/early Miocene, respectively (Fig. 5). In that context of rather rapid subsidence, the bank tops were unable to respond to a rapid rise in eustatic sea level associated with the general improvements of the global climate at the late Miocene/early Pliocene boundary. Finally, the drowning of the bank tops on the Queensland Plateau during the late Miocene and the early Pliocene possibly was also associated with unfavorable temperatures of the surface waters that were estimated, based on oxygen isotope in planktonic foraminifers, barely to have reached the minimum temperature necessary for coral growth during the late Miocene and the Pliocene (Isern et al., this volume). In summary, the shallow carbonate system on the Queensland Plateau is thought to have been deeply submerged, well below the photic zone, and thus drowned during the latest part of the Miocene and subsequently during the early Pliocene and to have become, therefore, an oceanic unproductive plateau at that time.

The following results from shipboard and post-cruise research illustrate that the recovery, at least partially, of the carbonate system on the Queensland Plateau, subsequent to its drowning during the late Miocene and early Pliocene, was clearly related to the lowering in sea level during the early late Pliocene. Variations of subsidence during the late Pliocene might also have played a secondary role in the partial recovery of the carbonate system on the Queensland Plateau. Using paleodepths of water as proxy for subsidence, Katz and Miller (this volume) show that Sites 813,814 , and 812 from the southwestern edge of the Queensland Plateau, display diachronous onset of rapid subsidence rates from west to east, during the late Miocene, the latest Miocene/early Pliocene, and the earliest part of the late Pliocene, respectively (Fig. 5). This pattern may reflect subsidence by flexure that propagated from wèst to east as a result of sediment loading along the northeastern Australia margin and in the Queensland and Townsville troughs. This model would imply lower subsidence rates during the late Pliocene in the area of the Queensland Plateau, where the modern reefs are located. These low subsidence rates would have favorably influenced their late Pliocene recovery and their ability to keep up with fluctuations in sea level during the late Pliocene and Quaternary.

\section{METHODS}

\section{Sediment Sampling and Analyses}

The interval between 85 and 200 mbsf of Hole $818 \mathrm{~B}$ and the interval between 70 and 186 mbsf of Hole $817 \mathrm{~A}$ were sampled every $50 \mathrm{~cm}$. Care was taken to avoid sampling obvious turbidite layers throughout Holes $818 \mathrm{~B}$ and $817 \mathrm{~A}$ and to avoid reworked or disturbed features at the top and bottom of each core. Each $10-\mathrm{cm}^{3}$ sediment sample was dried in an oven at $60^{\circ} \mathrm{C}$, weighed, and suspended in distilled water $(\mathrm{pH} 8)$. The coarse fraction of the sediment was separated from the fine fraction through a $63-\mu \mathrm{m}$ mesh sieve and then dried at $60^{\circ} \mathrm{C}$ and weighed again. The fine fraction $(<63-\mu \mathrm{m})$ was left 

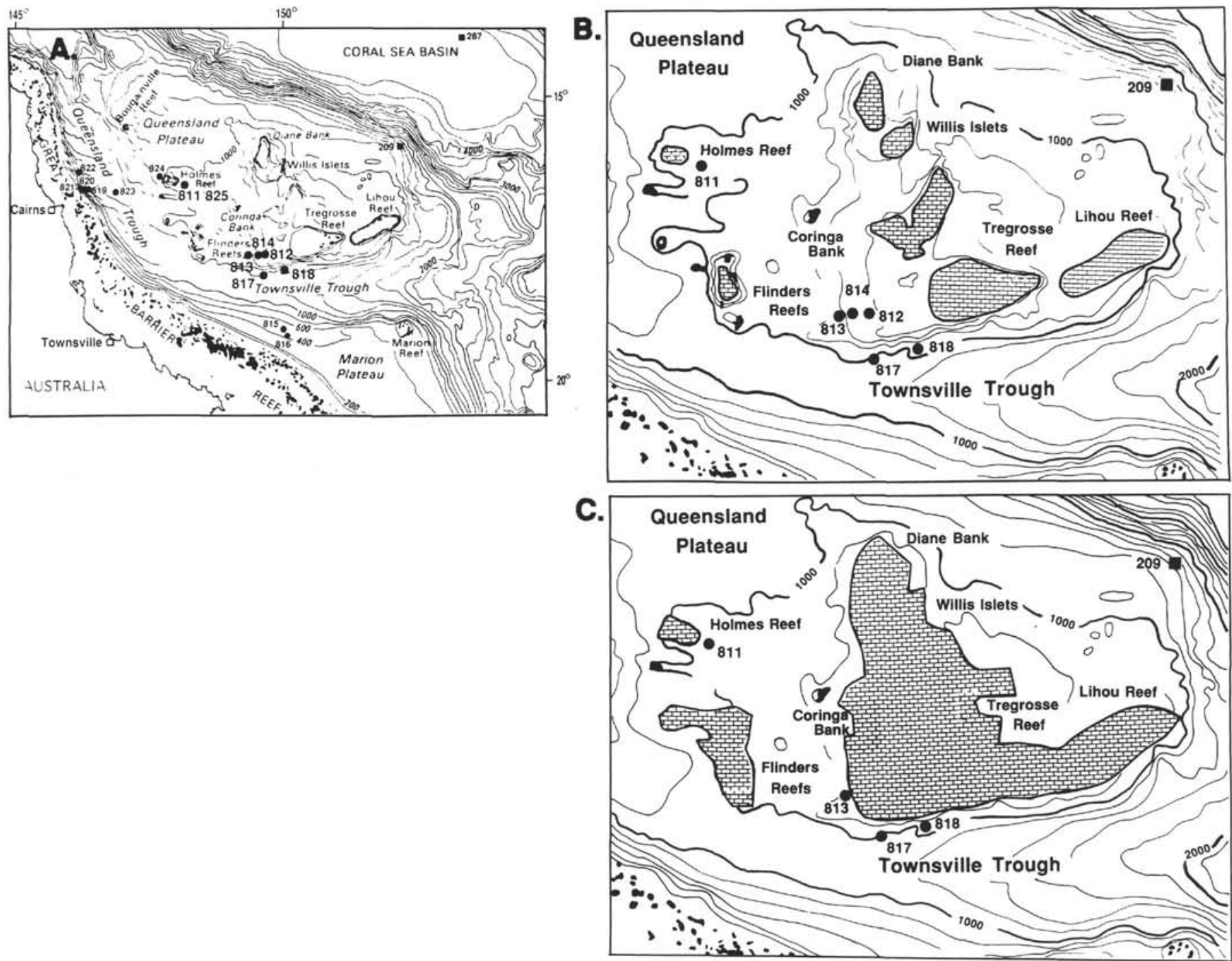

Figure 3. A. Map showing the modern northeastern Australia Margin and Great Barrier Reef, which are separated from the Marion and Queensland plateaus by the Queensland and Townsville troughs. The locations of Leg 133 sites are also shown. The latitude, longitude, and water depths for Sites $811,812,813,814,817$, and 818, used in this study, are included in Figure 5. B. Map of the Queensland Plateau with location of Sites 811, 812, 813,814, 817, and 818. The modern reefs are interpreted to represent the partial recovery at $2.9 \mathrm{Ma}$ of a much larger middle Miocene bank. C. Map of the Queensland Plateau showing the possible extent of shallow carbonate banks during the middle Miocene. These banks were exposed at the end of the middle Miocene (roughly $10 \mathrm{Ma}$ ) and subsequently drowned during the early and late Miocene.

to stand in distilled water for several days until the particles were completely settled and then was dried at $60^{\circ} \mathrm{C}$. The coarse fraction was used to estimate the degrees of cementation and overgrowth and to select monospecific samples of the planktonic foraminifer Globigerinoides sacculifer for oxygen isotope analyses. The fine fraction was used for carbonate-mineralogy analyses by X-ray diffraction (XRD) and for carbonate-content analyses by carbonate bomb.

\section{Carbonate Content in the Fine Fraction}

The carbonate-bomb method was used to determine the total carbonate content of the fine fraction in each sample from the $\mathrm{CO}_{2}$ pressure generated by dissolving the carbonate fraction in $50 \%$ concentrated HCL (Müller and Gastner, 1971). The pressure of $\mathrm{CO}_{2}$ released by the fraction of the carbonate with the acid was compared with pressure released by an equal amount of $100 \% \mathrm{CaCO}_{3}$ standard. Accuracy of the method for marine sediments remained within $\pm 2 \%$ for $\mathrm{CaCO}_{3}$ values that range between $5 \%$ and $95 \%$ (Birch, 1979).

\section{Carbonate Mineralogy of the Fine Fraction}

Relative proportions of the different carbonate minerals were quantified by XRD analyses. Each sample of fine sediment was dried at $60^{\circ} \mathrm{C}$, ground for $<1 \mathrm{~min}$ by hand in an agate mortar, sieved to obtain an agglomerate of $<63-\mu \mathrm{m}$ particles, and packed with a spatula into an aluminum sample holder. The effects of particle size on the semi-quantitative XRD estimate and the effects of mineralogy change by grinding are minimized through these procedures (Milliman, 1974). Each sample was analyzed with a Phillips-Norelco Model 12045 ( 60 cycles) diffractometer with dapple systems controller Thetaplus ${ }^{+}$software. The diffractometer setting used was at $35 \mathrm{kV}$ and $20 \mathrm{MA}$, and the analysis was conducted through a two-segmented scan from $25.5^{\circ}$ to $27.5^{\circ}$ for the aragonite primary peak and from $28.5^{\circ}$ to $32^{\circ}$ for the calcite and dolomite peaks, at a low scanning speed of $0.02 \%$ for optimal resolution. Areas under the aragonite peak, the dolomite peak (if present), and the calcite peaks (calcite and magnesian calcite) separated by deconvolution were calculated by integration of the counts under the 


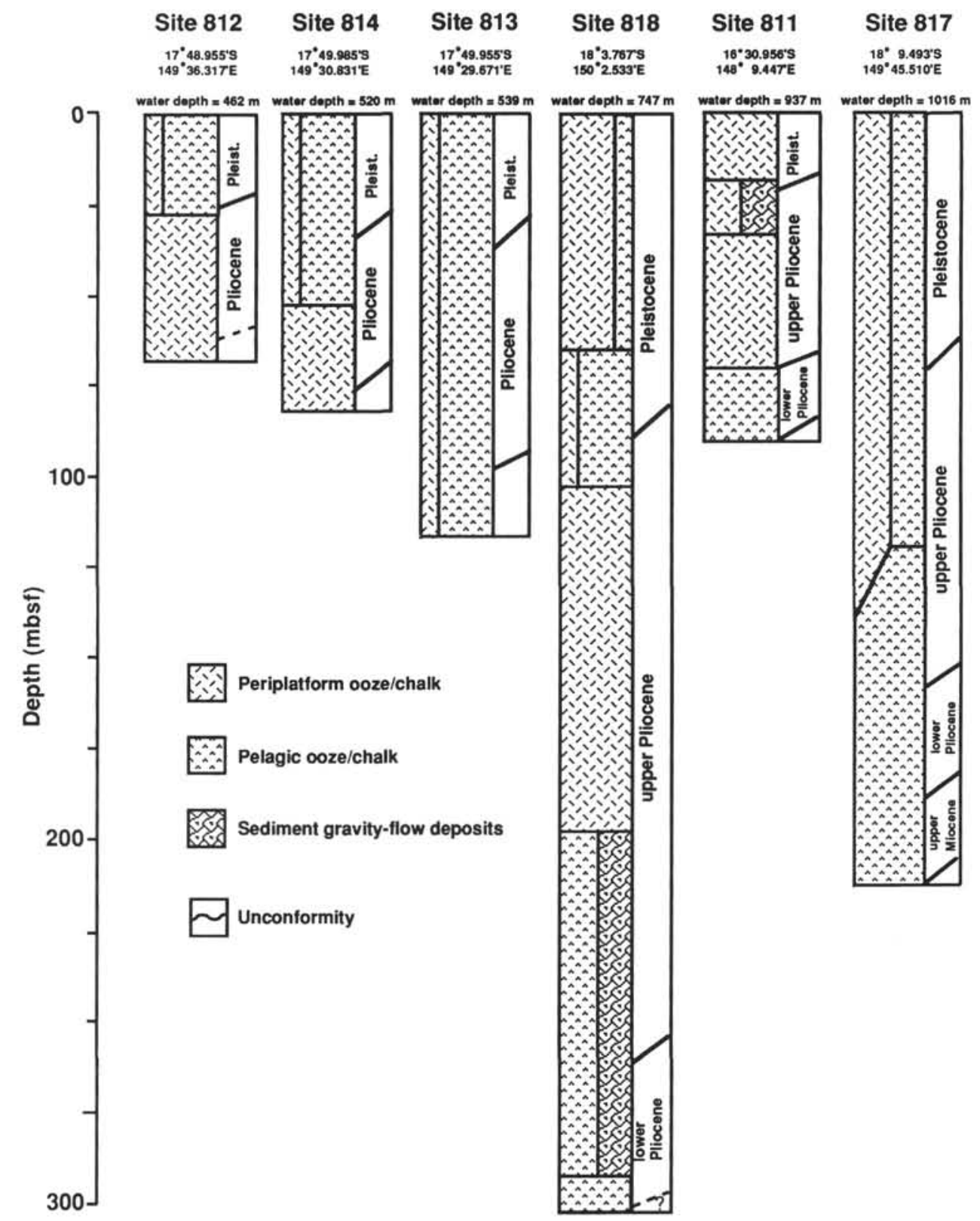

Figure 4. Lithostratigraphic summary of the Queensland Plateau sites for the Pliocene and the Quaternary. Note the pelagic character of the early Pliocene sediments in most of the sites (modified from Figs. 2 and 3; Chapter 3 of Davies, McKenzie, Palmer-Julson, et al., 1991).

respective peak and above the general noise background. The aragonite portion in each sample was calculated with an accuracy of better than 5\% from a calibration curve (Droxler, 1984). Reproducibility of the deconvolution method used to separate calcite from magnesian calcite is within a measured maximum discrepancy of $<5 \%$.

\section{Stratigraphies}

\section{Calcareous Nannofossil Biostratigraphy}

Nannostratigraphy datums are based on research done on board the ship during Leg 133 (Davies, McKenzie, Palmer-Julson, et al., 1991) and post-cruise onshore research by S. Gartner and W. Wei. We refer the reader to their respective chapters in this volume for more details of their respective methodologies.

\section{Planktonic Foraminifer Biostratigraphy}

Planktonic foraminifer datums are based on research performed on board the ship during Leg 133 (Davies, McKenzie, Palmer-Julson, et al., 1991) and post-cruise onshore research by D. Kroon. We refer the reader to his chapter in this volume for more details of his methodology.

\section{Magnetostratigraphy}

Magnetic polarity reversal stratigraphy was performed on discrete oriented samples collected on board the ship. The samples were measured with a cryogenic magnetometer in a magnetically shielded room at the University of Miami. Samples were subjected to progressive alternating-field demagnetization to assess stability and reliabil- 


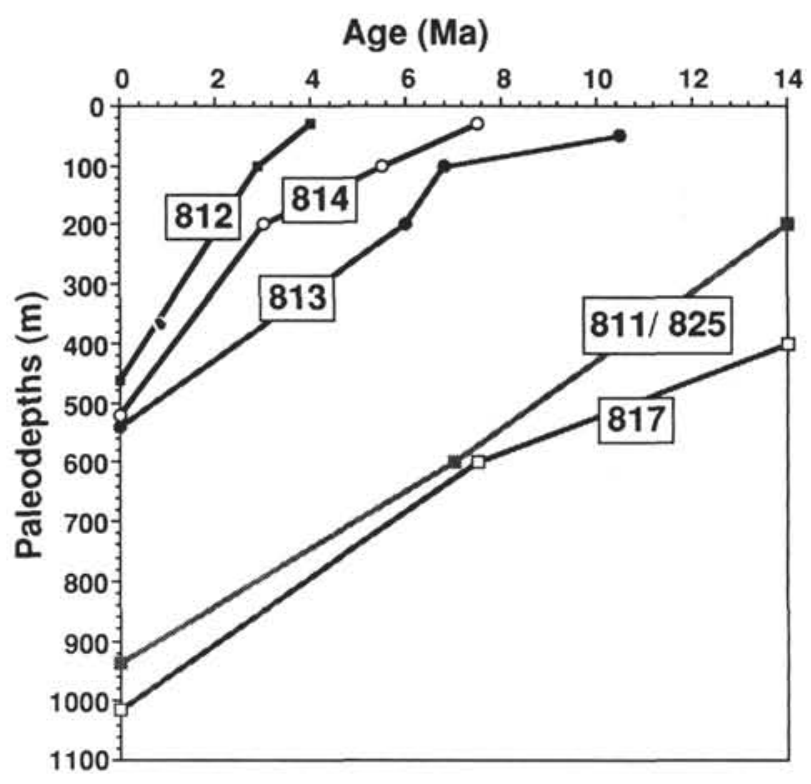

Figure 5. Variations with time (last 14 m.y.) of paleodepths, as a proxy for subsidence rates, based on assemblages of benthic foraminifers for five out of the six sites included in this study. The two deepest, Sites 811 and 817 , display fairly constant subsidence rates in the past 14 m.y. Sites 813,814 , and 812 , from the southwestern edge of the Queensland Plateau, display a diachronous onset of fast subsidence rates from west to east, during the late Miocene, the latest Miocene, and the earliest part of the late Pliocene, respectively. This pattern may reflect subsidence by flexure that propagated from west to east during the late Miocene through late Pliocene due to sediment loading along the northeastern Australia margin and in the Queensland and Townsville troughs.

ity of the orientation data. Details of the paleomagnetic results and methodology can be found in McNeill et al. (this volume).

\section{Oxygen Isotopes}

Oxygen isotopes were analyzed in Globigerinoides sacculifer for Hole $818 \mathrm{~B}$ between 84 and $200 \mathrm{mbsf}$ in two samples per section. For each sample, 20 to 30 foraminifer tests were selected in a narrow size fraction between 300 and $350 \mu \mathrm{m}$, cleaned ultrasonically to remove any calcareous mud clinging to the tests, and dried at $60^{\circ} \mathrm{C}$. Cleaned foraminifer tests were reacted with orthophosphoric acid at $90^{\circ} \mathrm{C}$ and the evolved $\mathrm{CO}_{2}$ gas was analyzed using a VG Isogas pricision isotope ratio mass (PRISM) (D. Kroon, University of Edinburgh, Stable Isotope Laboratory). Foraminifer samples were run with a stable marble reference (SMI) and measured values were converted to the PDB standard. Precision for $\delta^{18} \mathrm{O}$ analyses was $\pm 0.085 \%$ (the standard deviation for 100 analyses of SMI, performed over several months). Precision for $\delta^{13} \mathrm{C}$ analyses was $\pm 0.04 \%$.

\section{GENERAL PLIOCENE EVOLUTION OF THE CARBONATE SYSTEM ON THE QUEENSLAND PLATEAU}

\section{Pliocene Lithologies of Queensland Plateau Sites}

The lithologies in the six drilled sites on the Queensland Plateau are similar and display a fairly clear trend, in which the lower Pliocene sediments in general are more pelagic than the upper Pliocene sediments, which consist of a mixture of pelagic and bank-derived materials. Furthermore, sedimentation rates are usually higher for the upper than for the lower Pliocene sediments. The Pliocene lithologies recovered in the six Queensland Plateau sites are summarized for each individual site, from the shallowest to the deepest, in the following paragraphs and in Figure 4. Information was taken from Davies, McKenzie, Palmer-Julson, et al. (1991).

\section{Site 812}

A total of $40 \mathrm{~m}$ of Pliocene sediments was recovered in Site 812 . The upper part of the Pliocene sequence consists of foraminiferal oozes with bioclasts (essentially finer-grained planktonic foraminifer debris and bryozoan particles), whereas the lower part of the Pliocene sequence consists of micritic chalks, with variable proportions of foraminifers and nannofossils. A 1.5-cm-thick dolomitized limestone hardground characterized a condensed upper surface separates the lower from the upper part of the Pliocene sequence. The capping surface is composed of light reddish-brown fine laminations, presumably iron oxides and phosphate coatings. The degree of induration decreases downward from lithified grainstone to unlithified packstone.

\section{Site 814}

Forty-two meters of Pliocene sediments were recovered in Site 814. The upper part of the Pliocene sequence consists of nannofossil foraminiferal ooze intercalated with foraminiferal packstone, whereas the lower part is a micritic ooze with variable proportions of foraminifers and nannofossils. As in Site 812, a well-lithified, yellow-to-white, foraminiferal micritic limestone containing fish teeth and phosphate grains, capped by a hardground surface coated with an iron-rich crust, marks a sharp transition between the lower and upper parts of the Pliocene sequence.

\section{Site 813}

Sixty meters of Pliocene sediments were recovered in Site 813. The upper part of the Pliocene sequence consists of homogeneous, micritic, foraminifer to foraminifer-nannofossil ooze with bioclasts. The high nannofossil content $(50 \%-80 \%)$ is consistent with a predominantly pelagic origin for the ooze, but variable degrees of induration suggest that the flux of metastable bank-derived carbonates, which have a greater diagenetic potential, was not constant. The lower part of the Pliocene sequence consists of nannofossil foraminiferal oozes with micrite. This ooze is characterized by the presence of dark grains, in most of the cases corresponding to phosphatized benthic foraminifers. A salmon-colored foraminiferal ooze containing reddish-brown to reddish-yellow, presumably iron-stained, particles with mixed unaltered foraminifers, bioclasts, and undetermined grains makes the transition between the upper and lower parts of the Pliocene sequence.

\section{Site 818}

Two hundred and ten meters of Pliocene sediments were recovered in Site 818. The Pliocene sequence consists of homogeneous periplatform oozes composed of micrite and nannofossils with minor amounts of bioclasts and foraminifers. The upper part of the Pliocene sequence consists of nannofossil micrite ooze or micrite ooze having variable proportions of foraminifers and bioclasts with no turbidite layers or slump occurrence. The lower part of the Pliocene sequence is generally more pelagic than the upper part and consists of nannofossil oozes with variable proportion of foraminifers and micrite. In contrast with the upper part of the Pliocene sequence, numerous turbidites and several slumps occur in the lower part.

\section{Site 811}

Sixty nine meters of Pliocene sediments were recovered in Site 811. The upper part of the Pliocene sequence consists of foraminifer oozes with nannofossils and micrite and nannofossil oozes with foraminifers and micrite, intercalated with redeposited shallow-water carbonate sediments composed of unlithified bioclastic packstones with nannofossils and lithoclastic rudstones. The lower part of the 
Pliocene sequence consists of homogeneous nannofossils oozes with foraminifers to foraminifer oozes with nannofossils.

\section{Site 817}

Hundred and fourteen meters of Pliocene sediments were recovered in Site 817 that consisted of a highly bioturbated micritic ooze in the upper part of the Pliocene sequence and nannofossil ooze with foraminifers in the lower part of the sequence. Interbeds of graded foraminifer ooze (well-sorted sands) at several levels in the cores correspond to probable turbidite layers.

\section{Pliocene Age/Depth Curves}

The six periplatform sites cored on the Queensland Plateau during Leg 133 have been considered as two separate sets. The first set consists of relatively deep sites, namely in increasing water depths, Sites 818,811 , and 817 , and a second set of relatively shallow sites, namely in increasing water depths, Sites 812,814 , and 813. A compilation of age/depth curves, chiefly based on calcareous nannofossil and planktonic foraminifer biostratigraphies (see Table 1) are shown in Figures $6 \mathrm{~A}$ and $6 \mathrm{~B}$. Magnetostratigraphy, only available in the shallow sites and limited to the late Pliocene and Quaternary age sections, has been added to the data set to plot the age/depth curves. With a few exceptions, the biostratigraphies and magnetostratigraphy are in good agreement. Calcareous nannofossil biostratigraphy and magnetostratigraphy agree particularly well in sediments from the past $2.9 \mathrm{Ma}$ for the three shallow sites. The general trend of the Pliocene age/depth curves, already observed based on the shipboard data set and reinforced by results from our post-cruise research, was unexpected in the context of our previous results from studies of Pliocene periplatform sequences in the Bahamas and the Maldives (Droxler et al., 1988, 1990) (Fig. 1B).

Sedimentation rates in Sites 811, 817, 812, 813, and 814 display pelagic sedimentation rates that range between 11.5 to $25 \mathrm{~mm} / \mathrm{k}$.y. in the early Pliocene age section. In contrast, Site 818 , is characterized by very high sedimentation rates ( $114 \mathrm{~mm} / \mathrm{k} . \mathrm{y}$.), an order of magnitude higher than those for the early Pliocene sections in the five other sites. Lower Pliocene sediments in Sites 811 and 817 are mostly pelagic in nature. They can be classified either as nannofossil ooze with foraminifers or foraminifer ooze with nannofossils and are devoid of calciturbidite layers (Davies, McKenzie, Palmer-Julson, et al., 1991). For instance, calcareous nannofossils have been estimated to make up more than $75 \%$ of the fine fraction in Site 811 (Fig. 25, Sites $811 / 825$, Davies, McKenzie, Palmer-Julson, et al., 1991). Lower Pliocene sediments in Sites 812 and 814 consist of micrite oozes and chalks with nannofossils and planktonic foraminifers and, in Site 813, nannofossil foraminifer oozes with micrite. The lower Pliocene sediments in Site 818 , a site located on the middle slope, are always younger than $3.7 \mathrm{Ma}$ and, therefore, correspond only to the latest part of the early Pliocene. Their exceptionally high sedimentation rates can be explained by high proportions of redeposited sediment such as numerous turbidite layers and slumps separated by micrite nannofossil oozes and chalks.

At the very beginning of the late Pliocene section (3.5-2.9 Ma), either well-developed hardgrounds in Sites 812 and 814 or partially

Table 1. Age vs. depth datum levels, Holes $817 \mathrm{~A}$ and 817 B.

\begin{tabular}{clc}
\hline Age (Ma) & \multicolumn{1}{c}{ Datum levels } & Depth (mbsf) \\
\hline (1.56/2.29) & Hiatus & $(84.25 / 84.58)$ \\
1.60 & LAD G. fistulosis & 84.58 \\
2.29 & LAD D, pentaradiatus & 84.58 \\
2.42 & LAD D. surculus & 106.01 \\
2.6 & $\delta^{18} \mathrm{O}$ & 145 \\
2.6 & LAD D. Tamalis & 177.02 \\
2.9 & LAD Globoquadrina altispira & 193.05 \\
3.0 & LAD Sphaeroidinellopsis spp. & 196.7 \\
\hline
\end{tabular}

redeposited sediments by current transport in Site 813 characterized the sedimentation in the shallow sites. These hardgrounds consist of well-lithified, foraminifer micrite limestones several centimeters thick with fish teeth and phosphate grains and with several generations of iron-rich (goethite) cements and borings associated with vuggy porosity. The timing of the hardground formation is well constrained by calcareous nannofossil and foraminifer biostratigraphies as well as magnetostratigraphy and falls between 3.5 and $2.9 \mathrm{Ma}$. The upper Pliocene sediments overlying the hardground consist of either a highly condensed section of foraminifer ooze (averaged sedimentation rates, $3.6 \mathrm{~mm} / \mathrm{k.y}$.) in Site 812 or a pelagic section of nannofossil foraminifer oozes with minor foraminifer nannofossil oozes (averaged sedimentation rates, $20 \mathrm{~mm} / \mathrm{k}$.y.) in Site 814 . The sediments deposited in Site 813 during the early part of late Pliocene time, with an averaged sedimentation rate of $25.8 \mathrm{~mm} / \mathrm{k}$.y., can be classified as nannofossil foraminifer oozes with micrite, with characteristic darker-colored, sand-sized, iron-stained and phosphatized grains variably distributed throughout this interval. The characteristic presence of reworked phosphatized and/or ferruginized grains in Site 813, including lithoclasts and transported reefal benthic foraminifers, suggests a contribution of eroded sediments from a source area on the upper slope shallower than the area where Site 813 was drilled, in addition to planktonic particles that originated from the upper part of the water column. The area of Site 812 , where negligible sedimentation rates (i.e., $3.6 \mathrm{~mm} / \mathrm{k} . \mathrm{y}$.) were observed above the hardground, may have been the source for the redeposited sediments in Site 813.

In the deep sites, sedimentation rates in the early part of the late Pliocene section (2.9-2.4 Ma) are unusually high and decrease from $163 \mathrm{~mm} / \mathrm{k} . y$. in Site 818 , to $120 \mathrm{~mm} / \mathrm{k}$.y. in 817 and $47.5 \mathrm{~mm} / \mathrm{k}$.y. in Site 811. Lithologies in these three sites range from nannofossil oozes with foraminifers and bioclasts to micrite oozes with foraminifers and nannofossils. In Site 811, the proportion of nannofossils vs. micrite is decreasing from more than $60 \%$ at $2.9 \mathrm{Ma}$. to no more than $20 \%$ at $2.5 \mathrm{Ma}$ (Fig. 25, Sites 811/825, Davies, McKenzie, Palmer-Julson, et al., 1991). Finally, the late part of the late Pliocene is either missing in the two slope Sites 818 and 817 or the sedimentation rates for the sediments younger than 2.4 are more pelagic in character than the underlying sediments in Site 811 and have usually decreased relative to the early part of the late Pliocene, although between 2.0 and 1.6 $\mathrm{Ma}$, two distinct debris flows were observed.

In summary, the interval between 3.5 and $2.9 \mathrm{Ma}$ in the shallow sites is represented by either a hardground or pelagic sediments that consist partly of reworked sediments from a shallower area. The remaining of the late Pliocene section ( 2.9 to $1.6 \mathrm{Ma}$ ) is characterized by a condensed section in Site 812 and mostly by pelagic sediments in Sites 814 and 813. On the other hand, in the deep sites, the interval between 2.9 and 2.5 is characterized by unusually high sedimentation rates and micrite-rich sediments, whereas the rest of the late Pliocene section consists of sediments mostly pelagic in character with two debris flows and associated turbidites in Site 811 and by a major hiatus each in Sites 817 and 818. Based on these observations, the carbonate system on the Queensland Plateau is interpreted to have first been drowned during the early Pliocene highstand in eustatic sea level and then to have recovered at $2.9 \mathrm{Ma}$, at least partially, when compared with the middle Miocene extension of carbonate system, when sea level fell during the early part of the late Pliocene between 3.5 and 2.45 Ma. Results from post-cruise detailed studies in Hole 818B (see below) reinforce this interpretation.

\section{DETAILED LATE PLIOCENE (3.0-2.3 MA) EVOLUTION OF THE CARBONATE SYSTEM ON THE QUEENSLAND PLATEAU}

\section{Detailed Mineralogical and Isotopic Analyses of the Late Pliocene Sequence (3.0-2.3 Ma) from Hole 818B}

The Pliocene variations of (1) the carbonate, (2) the aragonite, and (3) the dolomite content in the fine fraction, (4) the oxygen and 
A
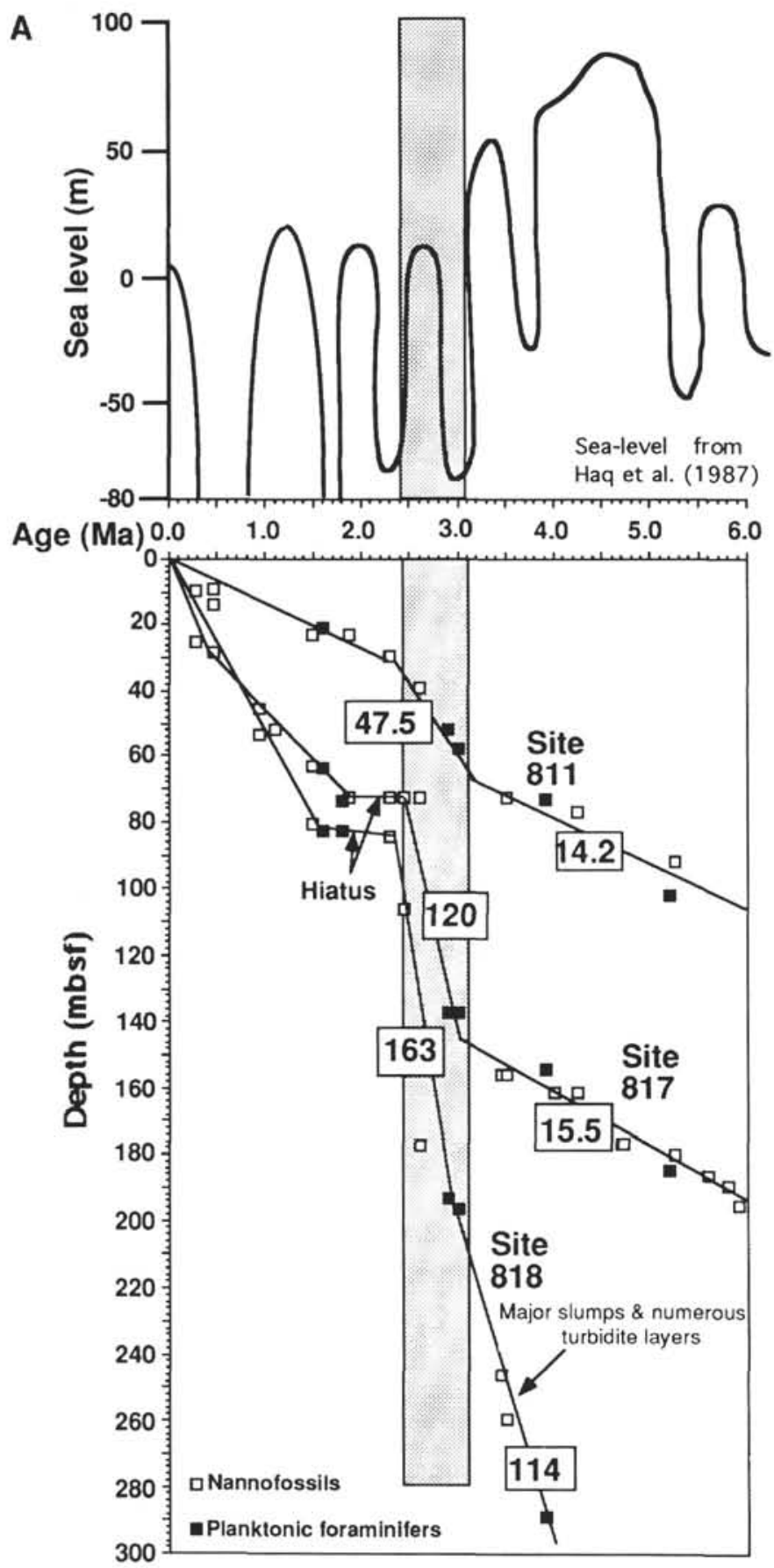

B

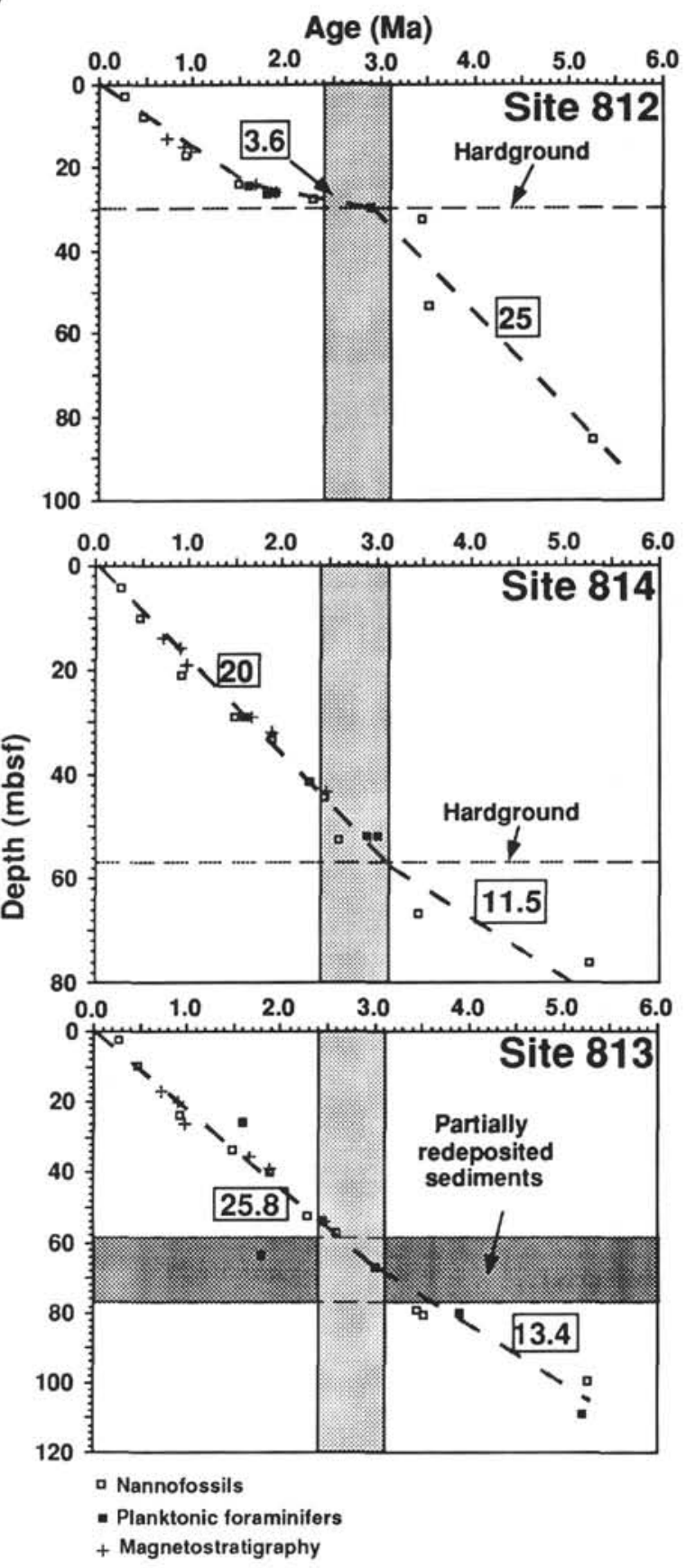

Figure 6. A. Pliocene sedimentation rates in the "deep" sites on the Queensland Plateau. Numbers in rectangles are averaged sedimentation rates in mm/k.y. or $\mathrm{m} / \mathrm{m} . \mathrm{y}$. The early Pliocene is characterized by typical pelagic sedimentation rates in Sites 811 and 817 , whereas sedimentation rates in Site 818 are high because of slumping and the occurrence of numerous turbidite layers. The early part of the late Pliocene (2.9-2.4 Ma) is characterized by high sedimentation rates that decrease from the closest site to a modern bank (Site 818) to the farthest site from a modern bank (Site 811). The late part of the Pliocene (2.4-1.6 Ma) is characterized by low sedimentation rates due to the occurrence of major hiatuses, most evident in Sites 818 and 817. B. Pliocene sedimentation rates in "shallow" sites on the Queensland Plateau. Numbers in rectangles are average sedimentation rates in $\mathrm{mm} / \mathrm{k} . \mathrm{y}$. or $\mathrm{m} / \mathrm{m}$.y. The early Pliocene is characterized by pelagic sedimentation rates in the three shallow sites. The timing of hardground formation in Sites 812 and 814 is estimated to span between 3.5 and $3.0 \mathrm{Ma}$. This interval corresponds to partially current-redeposited sediments in Site 813. The origin of the redeposited material is interpreted as being related to the winnowing of sediments from the shallower Sites 812 and 814 at the time of the hardground formation.

(5) carbon isotopes on monospecific samples of the planktonic foraminifer Globigerinoides sacculifer are plotted with age in Figure 7, using a simple age/depth model (Fig. 8) based on the biostratigraphic markers listed in Table 2 and constant sedimentation rates between the different biostratigraphic markers. These variations are tabulated in the appendix.
Values of carbonate content in the fine sediment fraction are very high in the Pliocene section of Hole $818 \mathrm{~B}$ and range between $95 \%$ and $99 \%$ (Fig. 7A). These high carbonate values show that the southern slope of the Queensland Plateau was at that time a pure carbonate system with little input of siliciclastic sediments. The Pliocene fine sediment fraction in Hole $818 \mathrm{~B}$ consists mainly of 
Table 2. Age vs. depth model, Site 811-817, 818.

\begin{tabular}{|c|c|c|c|c|c|c|c|}
\hline & \multirow[b]{2}{*}{ Age (Ma) } & \multicolumn{6}{|c|}{ Core depth (mbsf) } \\
\hline & & 811 & 812 & 813 & 814 & 817 & 818 \\
\hline \multirow[t]{20}{*}{ Calcareous nannofossils } & 0.28 & & 2.67 & 2.63 & 4.12 & 25.07 & 9.53 \\
\hline & 0.47 & 8.90 & 7.52 & 9.83 & 10.01 & 28.07 & 14.03 \\
\hline & 0.93 & & 17.02 & 23.82 & 21.01 & 45.56 & 53.51 \\
\hline & 1.10 & & & & & 51.56 & \\
\hline & 1.48 & 22.90 & 23.90 & 33.32 & 29.01 & 63.06 & 80.51 \\
\hline & 1.88 & 22.90 & 25.90 & 39.81 & 33.51 & 72.56 & \\
\hline & 2.29 & 29.40 & 27.37 & 52.31 & 41.51 & 72.56 & 84.58 \\
\hline & 2.44 & & & 53.81 & 44.51 & 72.56 & 106.01 \\
\hline & 2.60 & 38.90 & & 57.31 & 52.51 & 72.56 & 177.02 \\
\hline & 3.45 & & 32.33 & 79.31 & 66.83 & 155.70 & 246.08 \\
\hline & 3.51 & 72.60 & 53.61 & 80.81 & & 155.70 & 259.51 \\
\hline & 4.00 & & & & & 161.06 & \\
\hline & 4.24 & 76.90 & & & & 161.06 & \\
\hline & 4.70 & & & & & 176.70 & \\
\hline & 4.72 & & & & & 176.70 & \\
\hline & 5.25 & 91.60 & 85.61 & 99.81 & 76.00 & 180.07 & \\
\hline & 5.60 & & & & & 186.07 & \\
\hline & 5.80 & & & & & 189.57 & \\
\hline & 5.90 & & & & & 195.57 & \\
\hline & 6.74 & & & & & 200.56 & \\
\hline \multirow[t]{7}{*}{ Foraminifers } & 1.60 & 20.96 & 24.20 & 25.75 & 29.25 & 63.75 & 82.99 \\
\hline & 1.80 & & 26.20 & 63.76 & & 73.50 & 82.99 \\
\hline & 2.90 & 51.69 & 29.75 & & 51.95 & 137.25 & 193.05 \\
\hline & 3.00 & 57.65 & & 67.05 & 51.95 & 137.25 & 196.70 \\
\hline & 3.90 & 73.21 & & 80.25 & & 154.05 & 288.65 \\
\hline & 5.20 & 101.70 & & 108.75 & & 184.75 & \\
\hline & 10.40 & 150.48 & & & & & \\
\hline \multirow[t]{6}{*}{ Magnetostratigraphy } & 0.73 & & 13.00 & 17.00 & 14.00 & & \\
\hline & 0.91 & & 15.00 & 20.00 & 16.00 & & \\
\hline & 0.98 & & 16.00 & 26.00 & 19.00 & & \\
\hline & 1.66 & & 23.70 & 35.50 & 29.00 & & \\
\hline & 1.88 & & 26.00 & $39-00$ & 32.00 & & \\
\hline & 2.47 & & & 54.00 & 43.50 & & \\
\hline
\end{tabular}

calcite. Aragonite appears at $2.92 \mathrm{Ma}$ (194 mbsf, just $4 \mathrm{~m}$ below the first occurrence of dolomite) and systematically increases uphole for the rest of the Pliocene (Fig. 7B) and the Quaternary sections (Haddad et al., this volume). As soon as it appears in the fine fraction at 2.92 $\mathrm{Ma}$, the aragonite content displays cyclic variations, with cycle amplitude increasing from $12 \%$ at $2.92 \mathrm{Ma}$ to $20 \%$ at $2.46 \mathrm{Ma}$. Aragonite lows only reach a few percent between 2.92 and $2.5 \mathrm{Ma}$, but range between $10 \%$ and $15 \%$ between 2.5 and $2.3 \mathrm{Ma}$. Traces of dolomite (no more than $4 \%$ ) are only observed in the interval between 2.9 and $2.58 \mathrm{Ma}$ (190 and $130 \mathrm{mbsf}$ ).

Variations of the oxygen and carbon isotopes (Figs. 7D and 7E) display parallel trends. At the base of the Hole 818B Pliocene sequence during the interval between 2.93 and $2.78 \mathrm{Ma}$ (between 195 and $180 \mathrm{mbsf}$ ), the $\delta^{18} \mathrm{O}$ and $\delta^{13} \mathrm{C}$ isotopes systematically increase. This increase of the stable isotope values correlates with the first occurrence of aragonite and some dolomite in the fine sediment fraction. An increase of similar amplitude, especially in the $\delta^{18} \mathrm{O}$ variations, is observed between 2.48 and $2.4 \mathrm{Ma}$ (between 110 and $100 \mathrm{mbsf}$ ). Within the Hole $818 \mathrm{~B}$ late Pliocene sequence, the variations of $\delta^{18} \mathrm{O}$ and especially $\delta^{13} \mathrm{C}$ become more cyclic and appear to correlate well with the aragonite cycles in the fine fraction.

In other words, the two steps toward heavier oxygen isotopes in Hole 818B (Fig. 7D), roughly centered at 2.85 and $2.45 \mathrm{Ma}$, are synchronous with two major climatic events during the early part of the late Pliocene. These two major events are thought to correspond to a stepwise degradation of the climate and without any doubt to two major falls in sea level related to the initiation of glaciations in the Northern Hemisphere and to significant extension of the ice cap on Antarctica (Raymo et al., 1986; Jansen et al., in press; Hodell and Venz, 1992). The 2.85-Ma step toward heavier oxygen isotope values is marked by the first occurrence of aragonite, subsequently varying in a cyclic fashion, and dolomite as traces. This 2.85-Ma event also marks the onset of higher amplitudes and frequencies for the carbonate content variations in the fine sediment fraction. The second step toward heavier oxygen isotope values at $2.45 \mathrm{Ma}$ is clearly marked by well-developed aragonite cycles. Though the link between aragonite content and stable isotopes is not always straightforward, heavy $\delta^{18} \mathrm{O}$ and $\delta^{13} \mathrm{C}$ values tend to correspond to low aragonite values and vice versa. This trend is opposite to the light $\delta^{18} \mathrm{O}$ values that usually correspond to high aragonite content values systematically observed in Quaternary periplatform sequences in the Bahamas and the Maldives (Boardman et al., 1986; Droxler et al., 1983, 1988 and 1990), on the Nicaragua Rise (Glaser and Droxler, 1991), and on the Queensland Plateau (Haddad et al., this volume). Because 12 aragonite cycles can be identified in the interval between 2.9 and $2.4 \mathrm{Ma}$ (500 k.y.), one is tempted to consider these cycles as $40-k . y$. Milankovitch cycles and, therefore, to tie them to orbitally forced climatic cycles.

Contrary to the clear occurrence of aragonite in Hole $818 \mathrm{~B}$ in the late Pliocene age section, only calcite was detected by XRD in the fine carbonate fraction of Hole 817A in the Pliocene section, specifically during the interval of high sedimentation rates between 2.9 and $2.5 \mathrm{Ma}$. These results contrast with the occurrence of aragonite (up to $36 \%$ ) and traces of dolomite in Hole $818 \mathrm{~B}$ during the same time interval characterized by high sedimentation rates. Only traces of dolomite and aragonite were detected in Site 811 during the same early late Pliocene interval (Davies, McKenzie, Palmer-Julson, et al., 1991). On the other hand, systematically higher proportions of micrite in Sites 811, 817, and 818 , can be observed in the early part of the late Pliocene section $(2.9-2.5 \mathrm{Ma})$ than in the early Pliocene interval. The occurrence of micrite is interpreted to represent recrystalized bank-derived aragonite and magnesian calcite into the more stable carbonate phase of calcite through seafloor or shallow burial diagenetic processes.

\section{Calibration of the Late Pliocene Record (3.0-2.3 Ma) in Hole 818B with the High-resolution Oxygen Isotope Record from Hole 806B (Ontong Java Plateau)}

Though the late Pliocene planktonic oxygen isotope record from Hole $818 \mathrm{~B}$ in Fig. 7D shows a general increase of the $\delta^{18} \mathrm{O}$ values from 2.9 to $2.3 \mathrm{Ma}$, essentially through two steps at 2.85 and $2.45 \mathrm{Ma}$, the $\delta^{18} \mathrm{O}$ record lacks definition and details. To develop a better age control of the late Pliocene 2.9- to 2.3-Ma interval in Hole 818B and to compare a detailed $\delta^{18} \mathrm{O}$ record with the cyclic variations of fine aragonite (and to a certain degree fine dolomite) during that same interval, the $\delta^{18} \mathrm{O}$ record of Hole $818 \mathrm{~B}$ has been compared and visually correlated in Figure 9A with a newly published planktonic $\delta^{18} \mathrm{O}$ record from Ontong Java Plateau in Hole 806B (Jansen et al., in press). Maxima and minima of the Hole $806 \mathrm{~B} \delta^{18} \mathrm{O}$ record are visually correlated with the most defined peaks and lows of the Hole $818 \mathrm{~B}$ $\delta^{18} \mathrm{O}$ record (Fig. 9A). In Figure 9B, the two Hole $806 \mathrm{~B}$ and $818 \mathrm{~B}$ $\delta^{18} \mathrm{O}$ records, plotted together using the time scale of the Hole 806B $\delta^{18} \mathrm{O}$ record developed by Jansen et al. (in press), display sufficient similarities in their cyclic variations to substitute the Hole $806 \mathrm{~B} \delta^{18} \mathrm{O}$ record from Ontong Java Plateau for the Hole $818 \mathrm{~B} \delta^{18} \mathrm{O}$ record. In addition, Hole $806 \mathrm{~B} \delta^{18} \mathrm{O}$ record represents a global climate $\delta^{18} \mathrm{O}$ record because of the ideal equatorial location of Site 806 . The area of the Ontong Java Plateau (western equatorial Pacific Ocean) is characterized by ideal conditions (deep thermocline and low seasonality) to develop, from the oxygen isotopic composition of surface dwelling planktonic foraminifers Globigerinoides sacculifer, a global climate $\delta^{18} \mathrm{O}$ record with limited local temperature overprint on the effect of variations in global ice volume (Jansen et al., in press).

The $\delta^{18} \mathrm{O}$ record of Hole 806B shows a distinct decrease of the $\delta^{18} \mathrm{O}$ values $(0.9 \%)$ between 2.95 and $2.85 \mathrm{Ma}$, interpreted as an interval of enhanced ice volume and cooling trend (Jansen et al., in press, and Figure 9$)$. A $\delta^{18} \mathrm{O}$ increase of similar amplitude $(0.8 \%)$ has also been reported in North Atlantic Site 607 by Raymo et al. (1986) and Raymo (in press). Raymo has interpreted this $\delta^{18} \mathrm{O}$ increase as a cooling trend associated with the growth of significant continental ice sheets in the northern hemisphere equivalent to a fall in sea level of about $60 \mathrm{~m}$. Hodell and Venz (1992), based on the detailed study of 
A.

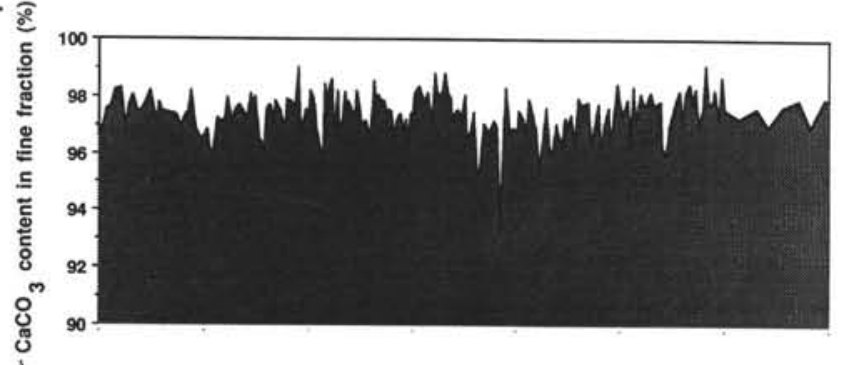

B.

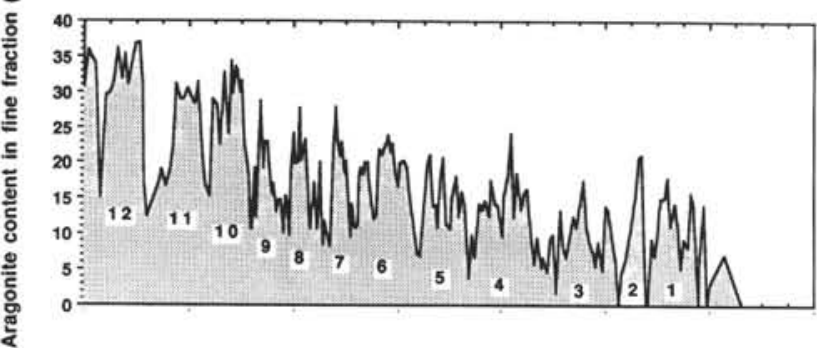

C. ระ

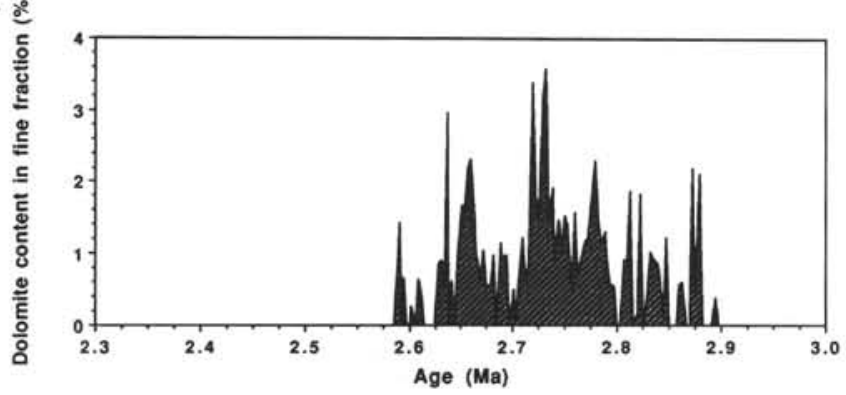

D.

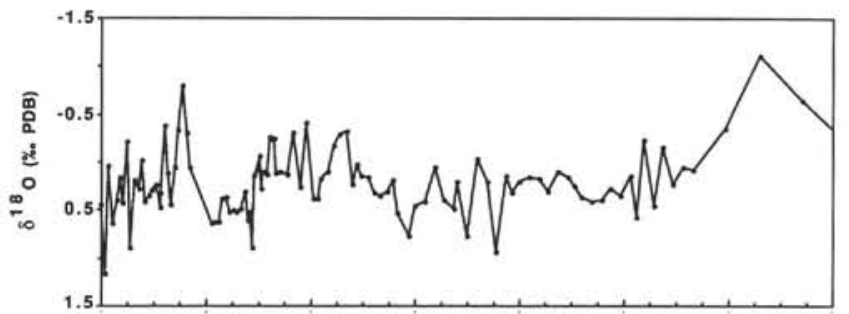

E.

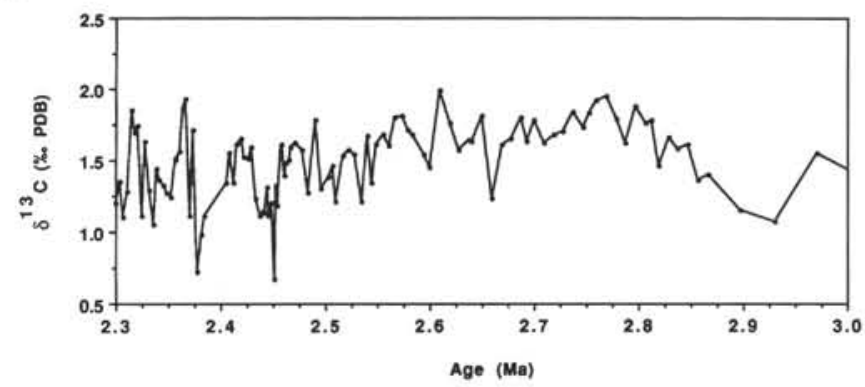

Figure 7. Time variations of $(\mathbf{A})$ carbonate, $(\mathbf{B})$ aragonite, and $(\mathbf{C})$ dolomite content in the fine sediments. Time variations of planktonic $(\mathbf{D}) \delta^{18} \mathrm{O}$ and $(\mathbf{F}) \delta^{13} \mathrm{C}$, based on Globigerinoides sacculifer. Variations of $\delta^{18} \mathrm{O}$ and $\delta^{13} \mathrm{C}$ display parallel trends. Note that the first appearance of aragonite and dolomite in the fine sediments, and the lowering of the carbonate content occur during the first step toward heavier oxygen isotopic ratios at $\sim 2.9$ Ma. Only trace amounts of dolomite $(<4 \%)$ occur between 2.9 and $2.6 \mathrm{Ma}$. Overall, aragonite variations show a gradual increase from 2.9 to $2.3 \mathrm{Ma}$ and display a cyclic pattern with a periodicity of roughly $40 \mathrm{k} . \mathrm{y}$. Between 2.9 and $2.45 \mathrm{Ma}$, high values of fine aragonite content seem to correspond to heavy foraminiferal $\delta^{18} \mathrm{O}$ and $\delta^{13} \mathrm{C}$ values.

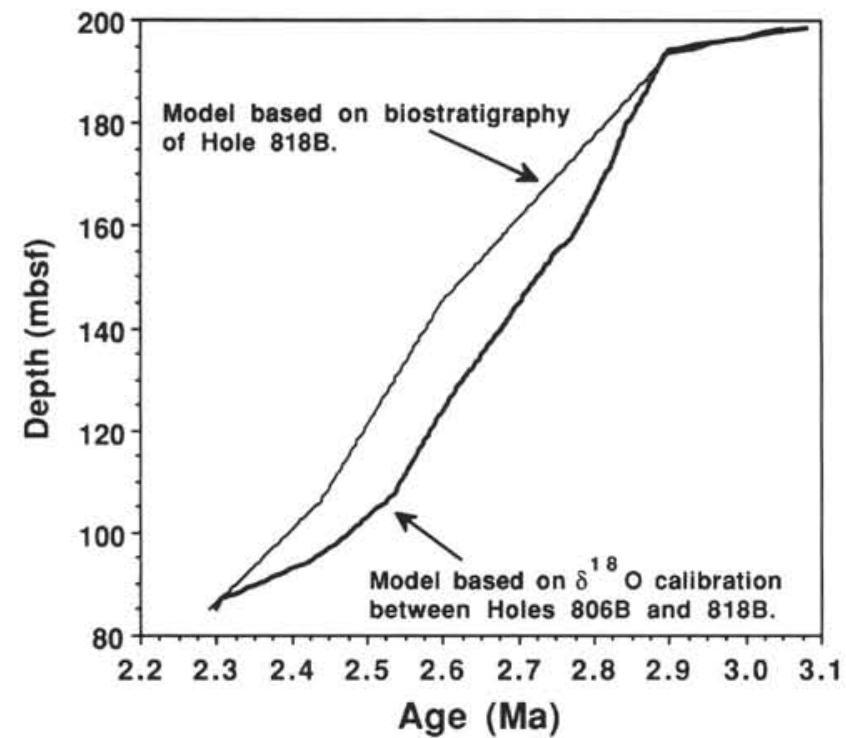

Figure 8. Comparison of two age-vs.-depth models, the first (thin black line) based on biostratigraphic markers from Hole $818 \mathrm{~B}$ and the second (thick black line) based on a calibration of $\delta^{18} \mathrm{O}$ record of Hole $818 \mathrm{~B}$ with the high-resolution $\delta^{18} \mathrm{O}$ record of Hole 806B from the Ontong Java Plateau (Jansen et al., in press).
Site 704 from the subantarctic South Atlantic Ocean, have also suggested a major shift of the climate mode within the Gauss between 2.9 and $2.7 \mathrm{Ma}$. This interval marks also the transition from a high-frequency variability at the precessional frequencies or even higher frequencies prior to 2.9 Ma to a strong 41 k.y. cyclicity in Sites 806,607 , and 704 .

The variations of fine aragonite and fine dolomite for Hole $818 \mathrm{~B}$ is plotted with the $\delta^{18} \mathrm{O}$ record of Hole $806 \mathrm{~B}$, used as a sea level proxy, for the interval between 2.9 and $2.3 \mathrm{Ma}$ (Figs. 10A and 10B). Variations of fine aragonite content and $\delta^{18} \mathrm{O}$ values display two modes of co-variance, confirming the trend already suggested by the comparison between the aragonite cycles and the Hole $818 \mathrm{~B} \delta^{18} \mathrm{O}$ record (Fig. 7). During a first interval between 2.9 and $2.5 \mathrm{Ma}$, the highest proportions of fine aragonite, with a few exceptions, correspond to the heaviest $\delta^{18} \mathrm{O}$ values or relative low sea level, whereas during the following interval between 2.5 and $2.3 \mathrm{Ma}$ the heaviest $\delta^{18} \mathrm{O}$ values, correspond to the lowest proportions of fine aragonite. The mode switch between aragonite and $\delta^{18} \mathrm{O}$ values co-variance followed the second step of $\delta^{18} \mathrm{O}$ decrease at $2.45 \mathrm{Ma}$.

The correlation between the dolomite content, though in trace amount, and the $\delta^{18} \mathrm{O}$ record on Hole $806 \mathrm{~B}$, the highest dolomite proportions corresponding to the lightest $\delta^{18} \mathrm{O}$ values, appear to be just opposite with the correlation between fine aragonite and $\delta^{18} \mathrm{O}$ values during the interval between 2.9 and $2.5 \mathrm{Ma}$. In spite of the occurrence of dolomite at trace levels and thus at the limit of XRD detection, it is interesting to mention that not only the onset of aragonite and dolomite 

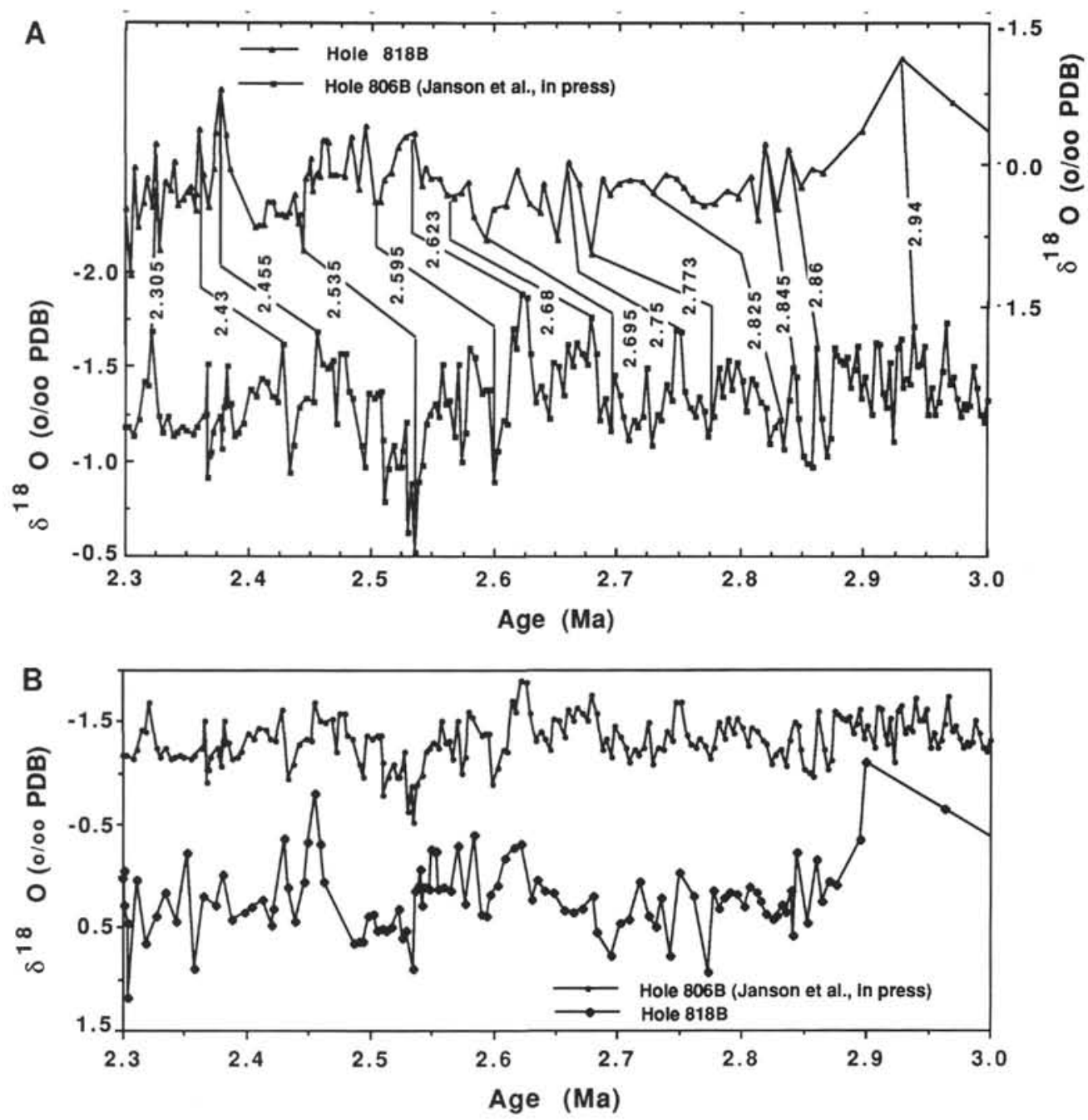

Figure 9. Calibration of planktonic $\delta^{18} \mathrm{O}$ record from Hole $818 \mathrm{~B}$ with a high-resolution planktonic $\delta^{18} \mathrm{O}$ record from Hole $806 \mathrm{~B}$ cored on Ontong Java Plateau (Jansen et al., in press). A. Visual correlation between the two $\delta^{18} \mathrm{O}$ records of the most important maxima and minima. Their respective ages, based on the age model developed by Jansen et al. (in press) for Hole 806B, also are indicated. B. Comparison of the $\delta^{18} \mathrm{O}$ records for Holes $818 \mathrm{~B}$ and $806 \mathrm{~B}$ after replotting the Hole $818 \mathrm{~B} \delta^{18} \mathrm{O}$ record using the age model of Hole $806 \mathrm{~B}$.

was synchronous and occurred during the first step of $\delta^{18} \mathrm{O}$ decrease at $2.85 \mathrm{Ma}$, but also the highest dolomite values appear to correspond to the lightest $\delta^{18} \mathrm{O}$ and the lowest aragonite values.

These observations regarding the relationship between the proportions of fine aragonite and dolomite and the $\delta^{18} \mathrm{O}$ values, used as a proxy for the high frequency $40 \mathrm{k} . y$. sea-level fluctuations, appear to be in a fairly good agreement with the "lowstand" scenario for carbonates illustrated in Figure 2. Jansen et al. (in press), Raymo (in press), and Hodell and Venz (1992) recently demonstrated that the interval between the two steplike $\delta^{18} \mathrm{O}$ increases at 2.85 and $2.45 \mathrm{Ma}$ was characterized by a strong $41 \mathrm{k} . y$. cyclicity in Sites 806,607 , and 704 (Fig. 11). Within this interval, the bank tops on the Queensland Plateau during the glacial stages (heavy $\delta^{18} \mathrm{O}$ values, low sea level), submerged within the photic zone under less water than during the interglacial stages (light $\delta^{18} \mathrm{O}$ values, high sea level) would have been more productive and, therefore, would have become larger exporter of fine aragonite during glacial than during interglacial stages. As mentioned in the previous paragraph, the highest proportions of fine aragonite, with a few exceptions, correspond to the heaviest $\delta^{18} \mathrm{O}$ values or relative low sea level. During interglacial stages, however, the bank tops, submerged under a water depth at the limit of the photic zone, would have decreased their production and export of fine aragonite, with prevalent production and export of fine magnesian calcite as on the modern bank tops submerged under water 40 to 80 $m$ deep along the Hawaiian Chain (Agegian and MacKenzie, 1992). This would explain the correlation of low aragonite proportions and the occurrence of dolomite traces (diagenetically altered magnesian calcite) with interglacial stages (low $\delta^{18} \mathrm{O}$ values). Subsequent to the second steplike $\delta^{18} \mathrm{O}$ increase at $2.5 \mathrm{Ma}$, sea level had fallen low enough for the bank tops to be emerged at some time and, therefore, to switch to the "highstand scenario," where as seen in Fig. 10B, the highest aragonite values correspond to the lightest $\delta^{18} \mathrm{O}$ values or interglacial stages.

\section{MODEL FOR THE PLIOCENE EVOLUTION OF THE CARBONATE SYSTEM ON THE QUEENSLAND PLATEAU}

Results from the detailed analyses of the Pliocene sequences from Hole $818 \mathrm{~B}$ have strengthened our first interpretation regarding the Pliocene pattern of sedimentation rates in the three "deep" Queensland Plateau Sites 818,817 , and 811. This pattern was unexpected 

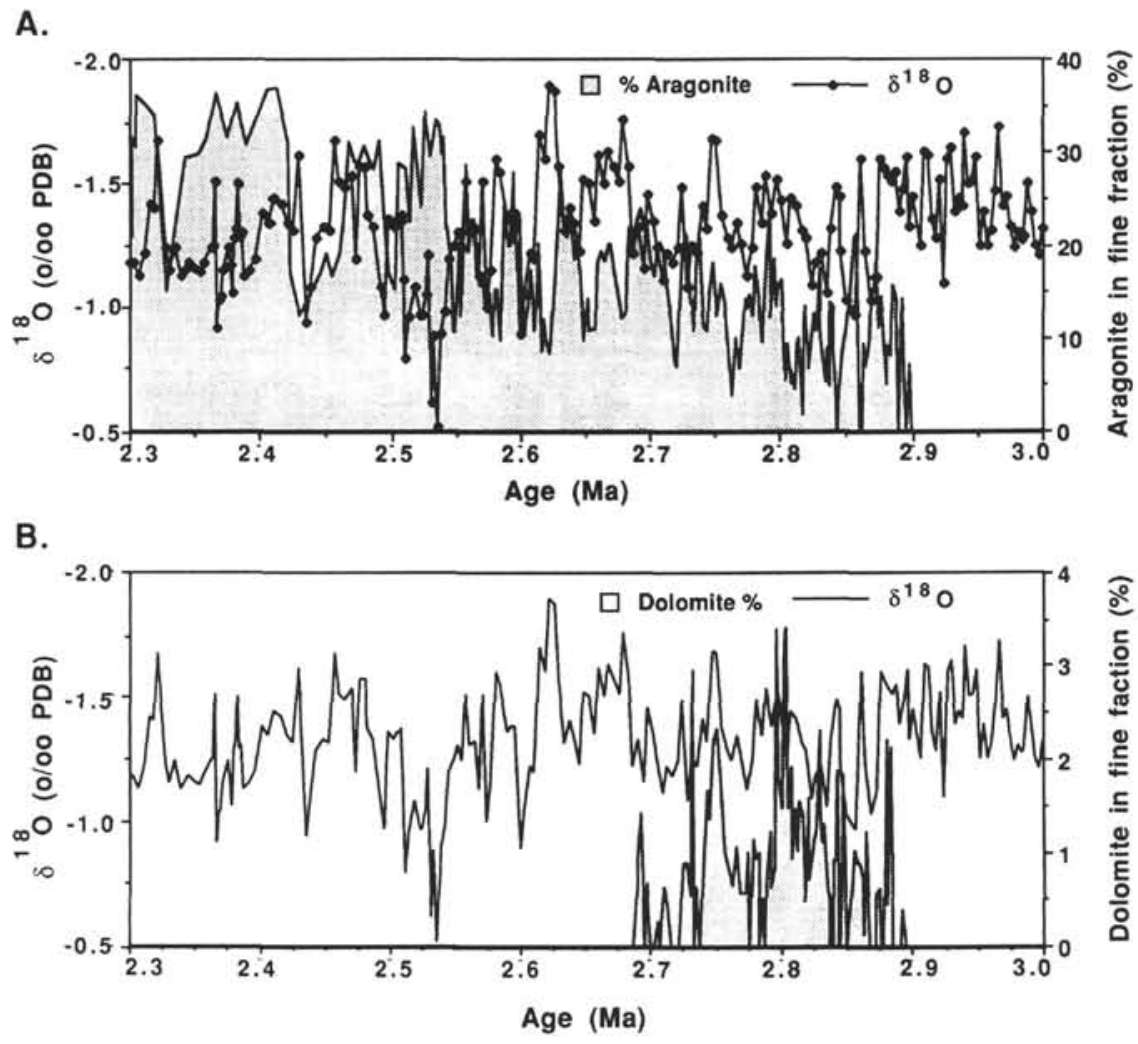

\begin{abstract}
Figure 10. Variations of (A) aragonite and (B) dolomite content in fine sediments plotted on top of the high-resolution $\delta^{18} \mathrm{O}$ record of Hole $806 \mathrm{~B}$, a proxy for sea-level fluctuations. Between 2.9 and $2.5 \mathrm{Ma}$, maximum aragonite values correspond to heavy $\delta^{18} \mathrm{O}$ values (lowstand), a possible illustration of "lowstand shedding" at a high-resolution scale of $40 \mathrm{k}$.y.-long cycles. Between 2.5 and $2.3 \mathrm{Ma}$, however, maximum aragonite content corresponds to light $\delta^{18} \mathrm{O}$ values (highstand), a possible illustration of "highstand shedding" at the high resolution scale of 40-100 k.y.-long cycles.
\end{abstract}

because it is just the opposite of the already established Pliocene pattern of sedimentation rates in similar depositional environments such as the Bahamas and the Maldives, with the latter interpreted in terms of variations in eustatic sea level directly related to worldwide Pliocene climatic events. Factors other than global climate and sealevel change might have influenced the Pliocene evolution of the Queensland Plateau. The difference in the pattern of sedimentation rates between the Queensland Plateau and the Bahamas/Maldives may be explained by the amplification of the rate of rise and fall in sea level through significant variations of the regional subsidence pattern and the regional conditions of oceanic surface temperatures among the three areas.

Climatically, the Pliocene can be subdivided into three intervals. The first interval consisted of a prolonged "interglacial" during the early Pliocene (5.0-3.6 Ma), characterized by an unusual highstand of sea level for the past 6 m.y. (Haq et al., 1987; Hodell and Kennett, 1986; Prentice and Matthews, 1988; Jansen et al., in press). This interval was followed by an intermediate interval characterized by gradual climatic deterioration from about 3.6 to about $2.9 \mathrm{Ma}$, and, finally, a series of glacial events at 2.85 (Raymo et al., 1986) and at $2.45 \mathrm{Ma}$ (Shackleton et al., 1984). On the other hand, the subsidence history of the Queensland Plateau, in spite of being poorly understood, appears to be characterized by progressively increasing rates of subsidence since the establishment of the shallow carbonate system during the Paleogene. In DSDP Site 209, an initial slow subsidence rate $(20 \mathrm{~mm} / \mathrm{k}$.y.) was followed by an increase subsidence rate to 40 $\mathrm{mm} / \mathrm{k}$.y. after the middle Miocene ( $11 \mathrm{Ma}$ ) and continued at that rate until the early Pliocene (Burns, Andrews, et al., 1973). This major late
Miocene age increase of subsidence, also recognized by Katz and Miller (this volume) based upon changes of benthic foraminiferal faunal assemblages, indicates a general deepening of the depositional environments during the latest Miocene at around $6 \mathrm{Ma}$ in sites 813 , 814, 817, and 811 (Fig. 5). For instance, in Sites 817 and 811, deepening by $6.8 \mathrm{Ma}$ to the middle bathyal zone was recognized, whereas in Sites 813 and 814, deepening to upper bathyal and outer shelf depths, respectively, was dated at around 6.5 Ma (Fig. 5). These fast subsidence rates might have amplified the already fast rise of eustatic sea level at the late Miocene/early Pliocene boundary (i.e., Haq et al., 1987) and might have contributed to the flooding of the Queensland Plateau top below the photic zones, a typical "gave-up situation" in terms of the response of a carbonate bank top to high rates of sea level rise. In Figure 12, we schematically illustrate our model and attempt to explain the pattern of sedimentation rates and lithologies we observed in the Pliocene sediments from the Queensland Plateau. The Pliocene evolution has been subdivided into three distinct intervals, described as follows:

\section{Early Pliocene (5.2-3.5 Ma) Global High Sea Level and Top of the Queensland Plateau Below the Photic Zone}

Evidence (Fig. 9A) points toward an interval of time of warmer and higher sea level during the early Pliocene (on the order of 60 to $100 \mathrm{~m}$ ) than today: (1) benthic and planktonic oxygen isotopic values decreased (Hodell and Kennett, 1986; Prentice and Matthews, 1988, respectively), which probably represents a decrease in global ice volume; (2) conditions in the sub-Antarctic Ocean were warmer, 


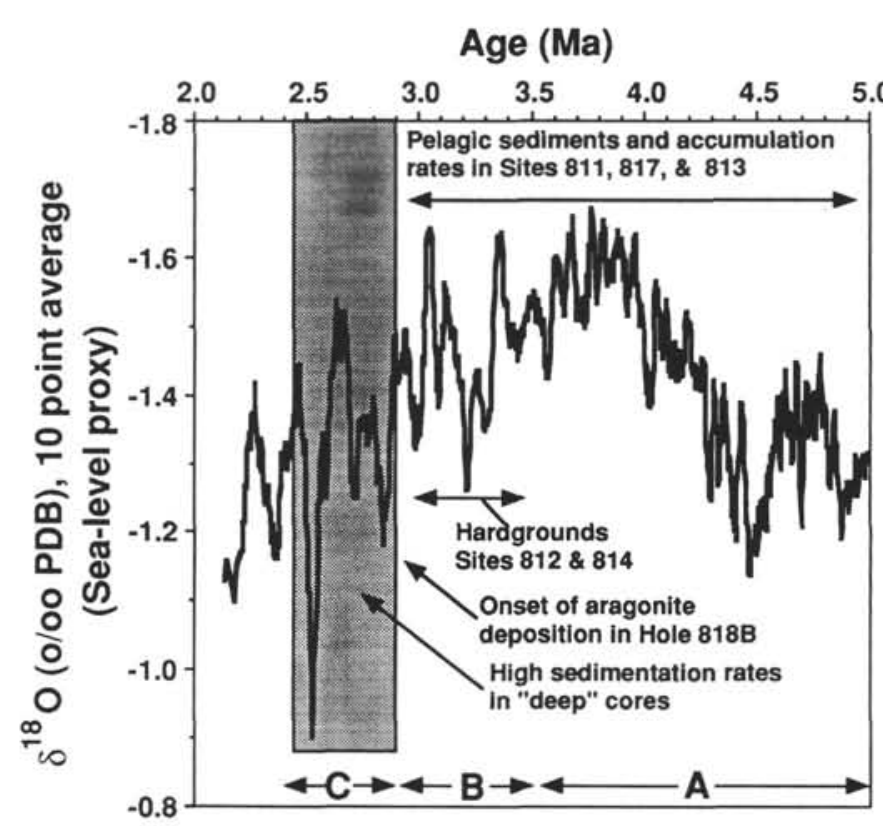

Figure 11. Planktonic foraminifer $\delta^{18} \mathrm{O}$ record (10 point average) between 5.0 and 2.0 Ma from Site 806 on Ontong Java Plateau (Jansen et al., in press), used as a proxy for variations in sea level. Events observed on the Queensland Plateau are shown relative to the proxy sea level curve (see also Fig. 12, where intervals A, B, and C are illustrated). Note the general lowering in sea level starting at $3.7 \mathrm{Ma}$. Hardgrounds in Sites 812 and 814 would be related to the first half of the lowering in sea level during the earliest part of the late Pliocene, whereas the high sedimentation rates in the "deep" cores would be related to the second half of the lowering in sea level (gray pattern). Note that the onset of fine aragonite in Hole $818 \mathrm{~B}$ correlates with a major lowering in sea level event at $2.9 \mathrm{Ma}$.

which probably resulted in melting the western Antarctic Ocean ice sheet, (3) major marine transgressions occurred at that time (i.e., Haq et al., 1987), for instance, flooding the Mediterranean and terminating evaporite deposition in that basin (Hodell and Kennett, 1986).

On the Queensland Plateau, the lower Pliocene (5.2-3.5 Ma) sediments are pelagic in nature and consist mostly of nannofossil and foraminifer oozes/chalks with some micrite, in the "deep" Sites 811 and 817 and most of the "shallow" Sites 812, 814, and 813 (Fig. 9A). Covering the shallowest part of the Queensland Plateau below the photic zone (therefore, at least deeper than $50 \mathrm{~m}$, see Glaser and Droxler, 1991) would have inhibited the benthic carbonate production and, therefore, may explain the absence of bank-derived material in the pelagic sediments deposited on the slopes and basins surrounding the Queensland Plateau isolated, drowned banks. This is a classic "gave up" response to the rapid eustatic rise in sea level at the beginning of the Pliocene (i.e., Haq et al., 1987), possibly even amplified by high subsidence rates during the latest part of the Miocene and the early Pliocene (see above). Early Pliocene modification of the general surface circulation on the Queensland Plateau may have resulted in the inhibition of reef growth by cooling the water temperature (Isern et al., this volume) or increasing the nutrient content. This scenario cannot be ruled out at the moment as an alternative explanation.

The earliest part of the late Pliocene, 3.5-2.9 Ma, is characterized by a lowering of sea level and wave base (Fig. 9B). Although the major late Pliocene lowering of sea level occurred at $2.4 \mathrm{Ma}$, the warm early Pliocene interval was terminated by a series of cooling and related falls in sea level as early as $3.6 \mathrm{Ma}$ by increased ice volume on Antarctica. Based upon our observations in the six different sites drilled on the Queensland Plateau, the amplitude of these sea-level lowerings were not large enough for the top of the Queensland Plateau to reenter the photic zone and initiate benthic carbonate production, as shown by the pelagic sedimentation characteristic of the deep Sites 811 and 817 . These falls in sea level might have been large enough, however, to influence the sedimentation in the "shallow" sites by lowering the wave base or by creating stronger currents at inter- mediate depths, to synchronously produce well-developed submarine hardgrounds in Sites 812 and 814 and a sedimentary sequence in Site 813 that consists of a mixture of pelagic and redeposited sediments from the adjacent shallower upslope area of Sites 812 and 814. In Site 818, a slope site, this interval was characterized by the occurrence of several slumps and numerous turbidites, possibly caused by slope instability related to a the general lowering of sea level (Crevello and Schlager, 1980).

\section{Early Late Pliocene (2.9-2.4 Ma), Top of Queensland Plateau Within the Photic Zone, Partial Recovery of the Shallow Carbonate System}

The interval between 2.9 and $2.4 \mathrm{Ma}$ is characterized by a series of events that led to stepwise climatic deteriorations from about 3.5 to about 2.6 Ma (Elmstrom and Kennett, 1986; Keigwin, 1986; Curry and Miller, 1989), and finally to a series of glacial events at $2.85 \mathrm{Ma}$ (Raymo et al., 1986) and at $2.45 \mathrm{Ma}$ (Shackleton et al., 1984). For instance, the 2.45-Ma event was actually a series of three discrete glacial pulses with spacing of about $40 \mathrm{k} . \mathrm{y}$. and an amplitude between one-half and two-thirds the scale of the late Quaternary glaciations (Sikes et al., 1991). As seen previously, the relatively short interval between 2.9 and $2.45 \mathrm{Ma}(0.45 \mathrm{Ma})$ corresponds to a distinct increase, at least by a factor of two and up to a factor of eight, of the sedimentation rates in four (Sites 811,814, 817, and 818) of the six sites drilled from the Queensland Plateau. This interval also corresponds to the first occurrence of bank-derived fine aragonite (and traces of dolomite) in Site 818, an indication that parts of the Queensland Plateau had reentered the photic zone and became the locations where benthic carbonate production had been re-initiated. The reentry of part of the Queensland Plateau into the photic zone, therefore, may be directly related to a series of eustatic lowerings of sea level that occurred between 2.9 and $2.45 \mathrm{Ma}$. The amplitude of these falls in sea level might have been modified by decreasing subsidence rates at that time on the area of the Queensland Plateau where the modern reefs are located.

\section{CONCLUSIONS}

Results of our research on the Pliocene sequences, drilled along a transect of six sites within the slope and basinal settings of the Queensland Plateau carbonate system, have shed some new light on the interpretation of periplatform sequences in terms of a true record of sea level. Results from several past studies of late Quaternary and Pliocene-Pleistocene periplatform sequences in the Bahamas and in the Maldives pointed out that "highstand shedding" was the typical response of carbonate platforms to fluctuations in sea level, a response opposite to "lowstand shedding," the commonly observed response of siliciclastic shelves to sea-level fluctuations.

Results from our research on the six Pliocene sequences drilled on the Queensland Plateau point out that high sedimentation rates and an admixture of bank-derived material to the pelagic sediments in periplatform sequences do not automatically record the flooding of a platform top following an interval of exposure. On the contrary, the Pliocene periplatform sequences on the Queensland Plateau appear to have recorded the reentry of the platform top into the photic zone after a lowering of sea level, following an interval characterized by high sea level, during which the shallow carbonate system was drowned. Sediments of early Pliocene age (5.2-3.5 Ma) deposited on the Queensland Plateau, an established interval of eustatic highstand in sea level, are essentially pelagic, whereas sediments of late Pliocene age (2.9-2.45 Ma), a well-established interval of eustatic lowering in sea level, are clearly periplatform in nature. On the other hand, sediments deposited during the transition interval (early late Pliocene, 3.5-2.9 Ma) between the early Pliocene highstand and the well- 
established late Pliocene eustatic lowering and lowstand in sea level appear to have recorded the beginning of sea level lowering by (1) the occurrence of synchronous submarine hardground in the two shallowest sites, (2) the deposition of reworked material from the shallower part of the margin in the intermediate sites, and (3) the deposition of pelagic sediments in the deepest sites. The Pliocene periplatform sequences clearly record a general shedding of the shallow carbonate system during an interval of well-established sea level lowering. Shedding of shallow carbonate material toward the deep slopes and basin floors clearly is tied to the position of the carbonate bank tops relative to the photic zone. The onset of shedding in periplatform sediments, therefore, has recorded either the flooding of the bank top within the photic zone during a rise in sea level following a period of exposure, a "highstand shedding" scenario, or the reentry of the bank top into the photic zone during a lowering in sea level following a period of drowning, a "lowstand shedding" scenario, which clearly is illustrated in the Pliocene periplatform sediments from the Queensland Plateau.

\section{ACKNOWLEDGMENTS}

This research was supported by a grant from USSAC-JOI to A.W. Droxler (Leg 133) and partially funded from the Donors of the Petroleum Research Fund administered by the American Chemical Society to A.W. Droxler. We are particularly grateful to W. Schlager and M.R. Boardman for their thorough reviews of the first manuscript, which greatly helped to improve the final version. E. Jansen made his unpublished data on $\delta^{18} \mathrm{O}$ on Hole $806 \mathrm{~B}$ available to us to strengthen the implication of sea level on our interpretation of Hole $818 \mathrm{~B}$. We also thank J. Mahr and V. Meyers for their invaluable assistance with sample preparation, processing, and XRD analyses.

\section{REFERENCES}

Agegian, C.R., and Mackenzie, F.T., 1989. Calcareous organisms and sediment mineralogy on a mid-depth bank in the Hawaiian Archipelago. Pac. Sci., 43:56-65.

Bard, E., Hamelin, B., and Fairbanks, R.G., 1990. U-Th ages obtained by mass spectrometry in corals from Barbados: sea level during the past 130,000 years. Nature, 346:456-458.

Birch, G.F., 1979. In-progress reports of the year 1978. Univ. Cape Town, Dep. Geol., Mar. Geol. Progr., Tech. Rep., 11:122-126.

Boardman, M.R., Baker, P.A., Dunn, L.A., Kenter, R.J., Hunter, G.E., and Kiefer, K.B., 1986. Banktop responses to Quaternary fluctuations in sea level recorded in periplatform sediments. Geology, 14:28-31.

Boardman, M.R., and Neumann, A.C., 1984. Sources of periplatform carbonates: Northwest Providence Channel, Bahamas. J. Sediment. Petrol., 54:1110-1112.

Burns, R.E., Andrews, J.E., et al., 1973. Init. Repts. DSDP, 21: Washington (U.S. Govt. Printing Office).

Crevello, P.D., and Schlager, W., 1980. Carbonate debris sheets and turbidites, Exuma Sound, Bahamas. J. Sediment. Petrol., 50:1121-1148.

Curry, W.B., and Miller, K.G., 1989. Oxygen and carbon isotopic variation in Pliocene benthic foraminifers of the equatorial Atlantic. In Ruddiman, W., Sarnthein, M., et al., Proc. ODP, Sci. Results, 108: College Station, TX (Ocean Drilling Program), 157-166.

Davies, P.J., McKenzie, J.A., Palmer-Julson, A., et al., 1991. Proc. ODP, Init. Repts., 133: College Station, TX (Ocean Drilling Program).

Droxler, A.W., 1984. Late Quaternary glacial cycles in the Bahamian Deep Basins and in the adjacent ocean [Ph.D. dissert.]. Univ. Miami, Coral Gables, FL.

Droxler, A.W., Bruce, C.H., Sager, W.W., and Watkins, D.H., 1988. PliocenePleistocene variations in aragonite content and planktonic oxygen-isotope record in Bahamian periplatform ooze, Hole 633A. In Austin, J.A., Jr.,

Abbreviations for names of organizations and publications in ODP reference lists follow the style given in Chemical Abstracts Service Source Index (published by American Chemical Society).
Schlager, W., et al., Proc. ODP, Sci. Results, 101: College Station, TX (Ocean Drilling Program), 221-244.

Droxler, A.W., Haddad, G.A., Mucciarone, D.A., and Cullen, J.L., 1990. Pliocene-Pleistocene aragonite cyclic variations in Holes 714A and 716B (The Maldives) compared with Hole 633A (The Bahamas): records of climate-induced $\mathrm{CaCO}_{3}$ preservation at intermediate water depths. In Duncan, R.A., Backman, J., Peterson, L.C., et al., Proc. ODP, Sci. Results, 115: College Station, TX (Ocean Drilling Program), 539-577.

Droxler, A.W., and Schlager, W., 1985. Glacial vs. interglacial sedimentation rates and turbidite frequency in the Bahamas. Geology, 13:799-802.

Droxler, A.W., Schlager, W., and Whallon, C.C., 1983. Quaternary aragonite cycles and oxygen-isotope record Bahamian carbonate ooze. Geology, 11:235-239.

Elmstrom, K.M., and Kennett, J.P., 1986. Late Neogene paleoceanographic evolution of Site 590: southwest Pacific. In Kennett, J.P., von der Borch, C.C., et al., Init. Repts. DSDP, 90 (Pt. 2): Washington (U.S. Govt. Printing Office), 1361-1381.

Feary, D.A., Davies, P.J., Pigram, C.J., and Symonds, P.A., 1991. Climatic evolution and control on carbonate deposition in Northeast Australia. Palaeogeogr., Palaeoclimatol., Palaeoecol., 89:341-361.

Glaser, K.S., and Droxler, A.W., 1991. High production and highstand shedding from deeply submerged carbonate banks, northern Nicaragua Rise. J. Sediment. Petrol., 61:128-142.

Haak, A.B., and Schlager, W., 1989. Compositional variations in calciturbidites due to sea-level fluctuations, Late Quaternary, Bahamas. Geol. Rundsch., $78: 477-486$.

Haq, B.U., Hardenbol, J., and Vail, P.R., 1987. Chronology of fluctuating sea levels since the Triassic. Science, 235:1156-1167.

Hodell, D.A., Elmstrom, K.M., and Kennett, J.P., 1986. Latest Miocene benthic $\delta^{i 8} 0$ changes, global ice volume, sea level, and the "Messinian salinity crisis." Nature, 320:411-414.

Hodell, D.A., and Kennett, J.P., 1986. Late Miocene-early Pliocene stratigraphy and paleoceanography of the South Atlantic and southwest Pacific Oceans: a synthesis. Paleoceanography, 1:285-311.

Hodell, D.A., and Venz, K., 1992. Toward a high-resolution stable isotopic record of the Southern Ocean during the Pliocene-Pleistocene ( 4.8 to 0.8 Ma). In Kennett, J.P., Warnke, D.A. (Eds.), The Antarctic Paleoenvironment: A Perspective on Global Change (Pt. 1). Antarc. Res. Ser., 56:265-310.

Jansen, E., Mayer, L.A., Backman, J., Leckie, R.M., and Takayami, T., in press. Evolution of Pliocene climate cyclicity at Site 806B (5-2 Ma): oxygen isotope record. $\ln$ Berger, W.H., Kroenke, L.W., Mayer, L.A., et al., Proc. $O D P$, Sci. Results, 130: College Station, TX (Ocean Drilling Program).

Keigwin, L.D., 1986. Pliocene stable-isotope record of Deep Sea Drilling Project Site 606: sequential events of ${ }^{18} \mathrm{O}$ enrichment beginning at $3.1 \mathrm{Ma}$. In Ruddiman, W.F., Kidd, R.B., Thomas, E., et al., Init. Repts. DSDP, 94 (Pt. 2): Washington (U.S. Govt. Printing Office), 911-920.

Labeyrie, L.D., Duplessy, J.C., and Blanc, P.L., 1987. Variations in mode of formation and temperature of oceanic deep waters over the past 125,000 years. Nature, 327:477-482.

Milliman, J.D., 1974. Marine Carbonates (2nd ed.): Berlin (Springer-Verlag).

Müller, G., and Gastner, M., 1971. The "Karbonat-bombe:" a simple device for determination of the carbonate content in sediments, soils and other materials. Neues. Jahrb. Mineral. Monatsh., 10:466-469.

Prentice, M.L., and Matthews, R.K., 1988. Cenozoic ice-volume history: development of a composite oxygen isotope record. Geology, 16:963-966.

Raymo, M.E., in press. Global climate change: a three million year perspective. In Interglacial-Glacial Transitions, NATO Trans.

Raymo, M.E., Ruddiman, W.F., and Clement, B.M., 1987. Pliocene-Pleistocene paleoceanography of the North Atlantic at DSDP Site 609. In Ruddiman, W.F., Kidd, R.B., Thomas, E., et al., Init. Repts. DSDP, 94 (Pt. 2): Washington (U.S. Govt. Printing Office), 895-901.

Schlager, W., 1981. The paradox of drowned reefs and carbonate platforms. Geol. Soc. Am. Bull., 92:197-211.

Shackleton, N.J., 1987. Oxygen isotopes, ice volume, and sea level. Quat. Sci. Rev., 6:183-190.

Shackleton, N.J., Backman, J., Zimmerman, H., Kent, D.V., Hall, M.A., Roberts, D.G., Schnitker, D., Baldauf, J., Desprairies, A., Homrighausen, R., Huddlestun, P., Keene, J.B., Kaltenback, A.J., Krumsiek, K.A.O., Morton, A.C., Murray, J.W., and Westberg-Smith, J., 1984. Oxygen isotope calibration of the onset of ice-rafting in DSDP Site 552A: history of glaciation in the North Atlantic region. Nature, 307:620-623. 
A.W. DROXLER ET AL.

Shipboard Scientific Party, 1988. Leg 101 - an overview. In Austin, J.A., Jr., Schlager, W., et al., Proc. ODP, Sci. Results, 101: College Station, TX (Ocean Drilling Program), 455-472.

Sikes, E.L., Keigwin, L.D., and Curry, W.B., 1991. Pliocene paleoceanography circulation and oceanographic changes associated with the 2.4 Ma glacial event. Paleoceanography, 6:245-258.

Symonds, P.A., and Davies, P.J., 1988. Structure, stratigraphy, evolution and regional framework of the Townsville Trough and Marion Plateau regionresearch cruise proposal, project 9131.11. Bur. Miner. Resour. Aust. Rec., $1988 / 48$.
Wilber, R.J., Milliman, J.D., and Halley, R.B., 1990. Accumulation of banktop sediment on the western slope of Great Bahama Bank: rapid progradation of a carbonate megabank. Geology, 18:970-974.

Date of initial receipt: 19 May 1992

Date of acceptance: 22 January 1993

Ms 133SR-227 
A. Early Pliocene, 5.2. to $3.5 \mathrm{Ma}$

General high sea level

Top of Queensland Plateau below the photic zone

$\$$

\section{Photic zone}

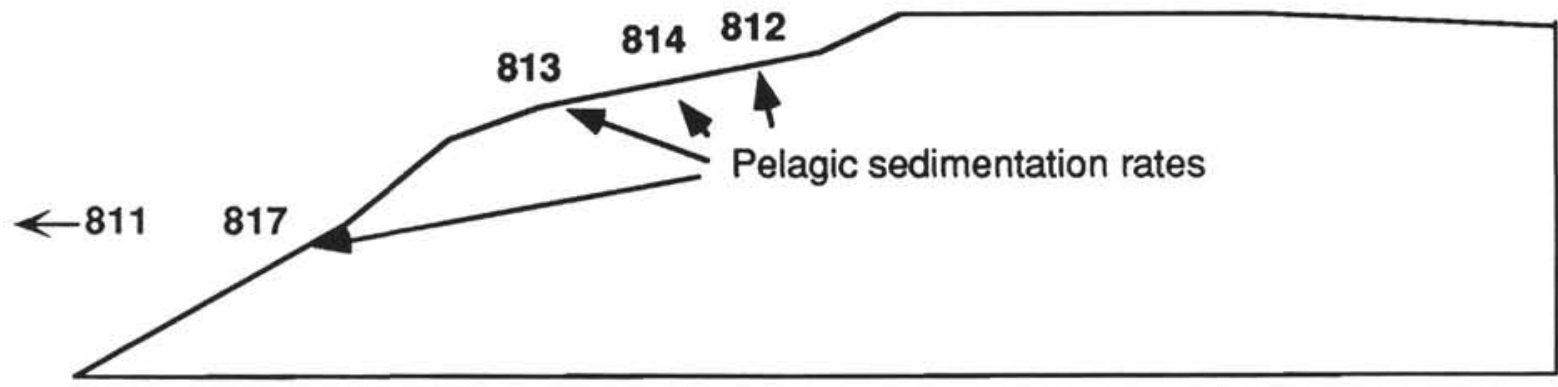

B. Ealiest part of the late Pliocene, 3.5 to $2.9 \mathrm{Ma}$

Lowering of sea level and wave base

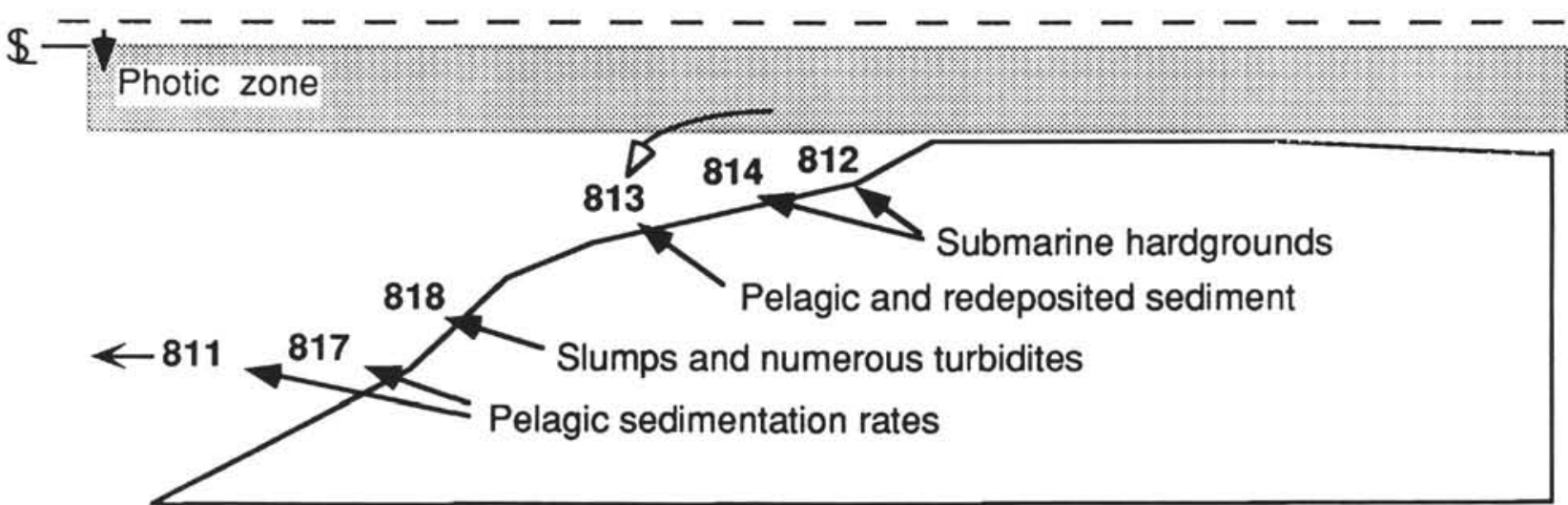

C. Early late Pliocene, 2.9 to $2.4 \mathrm{Ma}$

Top of Queensland Plateau within the photic zone

Partial recovery of shallow carbonate system

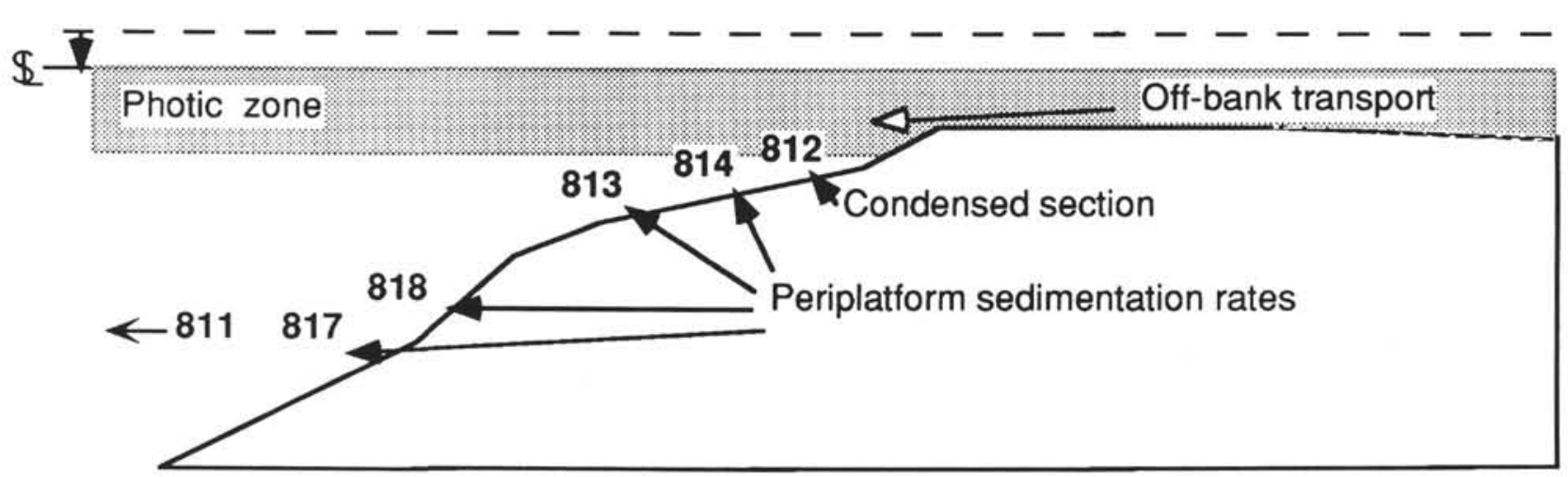

Figure 12. Model used to interpret the Pliocene sedimentary record of the Queensland Plateau by three successive phases. A. Drowning of the Queensland Plateau top during the early Pliocene and the deposition of pelagic sediments in the sites drilled to the southwest of the plateau. B. Lowering in sea level during the earliest part of the late Pliocene would explain (1) the occurrence of submarine hardgrounds in Sites 812 and 814 , "shallow" sites, (2) the mixture of pelagic and redeposited sediments in Site 813, (3) gravity-related deposits in the Site 818, a "deep" site, and (4) pelagic sediments in Sites 817 and 811. C. Initiation of benthic carbonate production and off-bank transport of excess production during the early late Pliocene resulting from the reentry of the Queensland Plateau bank tops into the photic zone. Periplatform sediments are observed in the "shallow" and "deep" sites. 
APPENDIX

Carbonate Mineralogy

\begin{tabular}{|c|c|c|c|c|c|c|c|c|c|}
\hline $\begin{array}{l}\text { Depth } \\
\text { (mbsf) }\end{array}$ & $\begin{array}{l}\text { Biostrat. } \\
\text { Age (Ma) }\end{array}$ & $\begin{array}{c}\delta^{18} \mathrm{O}^{*} \\
\text { Age }(\mathrm{Ma})\end{array}$ & $\begin{array}{c}\text { Fine } \\
\text { fraction }(\%)\end{array}$ & $\begin{array}{c}\text { Fine } \\
\text { carbonate }(\%)\end{array}$ & $\begin{array}{c}\text { Fine } \\
\text { calcite (\%) }\end{array}$ & $\begin{array}{c}\text { Fine } \\
\text { aragonite (\%) }\end{array}$ & $\begin{array}{c}\text { Fin } \\
\text { dolomite }(\%)\end{array}$ & $\begin{array}{c}\delta^{18} \mathrm{O}_{\mathrm{PDB}} \\
\text { G. sacculifer }(\% \circ)\end{array}$ & $\begin{array}{c}\delta^{3} \mathrm{C}_{\mathrm{PDB}} \\
\text { G. sacculifer }(\% 0)\end{array}$ \\
\hline 84.65 & 2.290 & 2.300 & 71 & 98 & 79 & 21 & 0 & 0.020 & 1.521 \\
\hline 85.15 & 2.294 & 2.301 & 77 & 98 & 79 & 21 & 0 & -0.051 & 1.484 \\
\hline 85.55 & 2.297 & 2.302 & 79 & 97 & 68 & 32 & 0 & 0.282 & 0.872 \\
\hline 86.05 & 2.300 & 2.304 & 79 & 97 & 69 & 31 & 0 & 0.455 & 1.202 \\
\hline 86.65 & 2.304 & 2.305 & 80 & 97 & 64 & 36 & 0 & 1.177 & 1.346 \\
\hline 87.05 & 2.307 & 2.311 & 80 & 98 & 65 & 35 & 0 & 0.047 & 1.104 \\
\hline 87.55 & 2.311 & 2.319 & 71 & 98 & 66 & 34 & 0 & 0.651 & 1.283 \\
\hline 88.15 & 2.315 & 2.328 & 65 & 98 & 85 & 15 & 0 & 0.399 & 1.855 \\
\hline 88.55 & 2.318 & 2.335 & 88 & 98 & 77 & 23 & 0 & 0.160 & 1.692 \\
\hline 89.05 & 2.321 & 2.343 & 63 & 98 & 71 & 29 & 0 & 0.437 & 1.741 \\
\hline 89.65 & 2.325 & 2.352 & 59 & 97 & 70 & 30 & 0 & -0.216 & 1.106 \\
\hline 90.05 & 2.328 & 2.358 & 69 & 98 & 69 & 31 & 0 & 0.901 & 1.632 \\
\hline 90.55 & 2.332 & 2.366 & 74 & 98 & 64 & 36 & 0 & 0.195 & 1.288 \\
\hline 91.15 & 2.336 & 2.375 & 73 & 97 & 68 & 32 & 0 & 0.289 & 1.047 \\
\hline 91.55 & 2.339 & 2.382 & 82 & 97 & 65 & 35 & 0 & -0.011 & 1.439 \\
\hline 92.05 & 2.342 & 2.389 & 64 & 98 & 69 & 31 & 0 & 0.419 & 1.359 \\
\hline 92.65 & 2.346 & 2.399 & 76 & & & & & 0.359 & 1.321 \\
\hline 93.05 & 2.349 & 2.405 & 79 & 98 & 63 & 37 & 0 & 0.301 & 1.268 \\
\hline 93.55 & 2.353 & 2.413 & 80 & 97 & 63 & 37 & 0 & 0.242 & 1.244 \\
\hline 94.05 & 2.356 & 2.421 & 71 & 97 & 69 & 31 & 0 & 0.485 & 1.514 \\
\hline 94.12 & 2.357 & 2.422 & 88 & 98 & 83 & 17 & 0 & 0.326 & 1.499 \\
\hline 94.65 & 2.360 & 2.430 & 85 & 98 & 88 & 12 & 0 & -0.369 & 1.565 \\
\hline 95.05 & 2.363 & 2.434 & 91 & & & & & 0.115 & 1.857 \\
\hline 95.55 & 2.367 & 2.439 & 79 & & & & & 0.449 & 1.926 \\
\hline 96.15 & 2.371 & 2.446 & 88 & 97 & 83 & 17 & 0 & 0.058 & 1.109 \\
\hline 96.55 & 2.374 & 2.450 & 88 & 97 & 81 & 19 & 0 & -0.329 & 1.711 \\
\hline 97.05 & 2.377 & 2.455 & 90 & 97 & 83 & 17 & 0 & -0.796 & 0.716 \\
\hline 97.65 & 2.381 & 2.460 & 90 & 97 & 81 & 19 & 0 & -0.306 & 0.976 \\
\hline 98.05 & 2.384 & 2.463 & 85 & 97 & 77 & 23 & 0 & 0.058 & 1.109 \\
\hline 98.55 & 2.388 & 2.467 & 82 & 98 & 69 & 31 & 0 & & \\
\hline 99.15 & 2.392 & 2.472 & 80 & 97 & 71 & 29 & 0 & & \\
\hline 99.55 & 2.395 & 2.475 & 84 & 97 & 71 & 29 & 0 & & \\
\hline 100.05 & 2.398 & 2.479 & 77 & 96 & 69 & 31 & 0 & & \\
\hline 100.65 & 2.402 & 2.484 & 75 & 97 & 71 & 29 & 0 & & \\
\hline 101.05 & 2.405 & 2.487 & 73 & 96 & 72 & 28 & 0 & 0.648 & 1.341 \\
\hline 101.55 & 2.409 & 2.491 & 90 & 96 & 69 & 31 & 0 & 0.630 & 1.554 \\
\hline 102.14 & 2.413 & 2.495 & 84 & 97 & 79 & 21 & 0 & 0.630 & 1.340 \\
\hline 102.55 & 2.416 & 2.499 & 89 & 97 & 83 & 17 & 0 & 0.386 & 1.606 \\
\hline 103.05 & 2.419 & 2.503 & 92 & 97 & 85 & 15 & 0 & 0.377 & 1.650 \\
\hline 103.55 & 2.423 & 2.506 & 92 & 98 & 71 & 29 & 0 & 0.528 & 1.518 \\
\hline 104.15 & 2.427 & 2.511 & 92 & 97 & 72 & 28 & 0 & 0.510 & 1.510 \\
\hline 104.55 & 2.430 & 2.514 & 87 & 97 & 78 & 22 & 0 & 0.532 & 1.592 \\
\hline 105.05 & 2.433 & 2.518 & 89 & 98 & 67 & 33 & 0 & 0.496 & 1.227 \\
\hline 105.65 & 2.437 & 2.523 & 90 & 97 & 76 & 24 & 0 & 0.318 & 1.114 \\
\hline 106.05 & 2.440 & 2.526 & 90 & 97 & 66 & 34 & 0 & 0.610 & 1.138 \\
\hline 106.55 & 2.442 & 2.530 & 92 & 97 & 70 & 30 & 0 & 0.526 & 1.130 \\
\hline 107.15 & 2.445 & 2.535 & 86 & 98 & 66 & 34 & 0 & 0.901 & 1.309 \\
\hline 107.55 & 2.446 & 2.537 & 88 & 98 & 67 & 33 & 0 & 0.146 & 1.112 \\
\hline 108.05 & 2.448 & 2.539 & 94 & 98 & 70 & 30 & 0 & 0.088 & 1.203 \\
\hline 108.65 & 2.451 & 2.541 & 93 & 97 & 68 & 32 & 0 & -0.063 & 0.673 \\
\hline 109.05 & 2.452 & 2.542 & 93 & 96 & 78 & 22 & 0 & 0.284 & 1.324 \\
\hline 109.55 & 2.454 & 2.544 & 91 & 96 & 79 & 21 & 0 & 0.109 & 1.179 \\
\hline 110.15 & 2.457 & 2.547 & 93 & 96 & 82 & 18 & 0 & 0.102 & 1.560 \\
\hline 110.55 & 2.459 & 2.548 & 90 & 97 & 89 & 11 & 0 & 0.135 & 1.611 \\
\hline 111.05 & 2.461 & 2.550 & 92 & 98 & 89 & 11 & 0 & -0.254 & 1.385 \\
\hline 111.65 & 2.463 & 2.553 & 87 & 98 & 81 & 19 & 0 & -0.245 & 1.479 \\
\hline 112.05 & 2.465 & 2.554 & 91 & 98 & 88 & 12 & 0 & -0.240 & 1.501 \\
\hline 112.55 & 2.467 & 2.556 & 85 & 97 & 76 & 24 & 0 & 0.125 & 1.587 \\
\hline 113.05 & 2.469 & 2.558 & 80 & 98 & 71 & 29 & 0 & & \\
\hline 113.65 & 2.471 & 2.560 & 92 & 98 & 81 & 19 & 0 & 0.106 & 1.625 \\
\hline 114.05 & 2.473 & 2.562 & 73 & 98 & 77 & 23 & 0 & & \\
\hline 114.60 & 2.475 & 2.564 & 82 & 97 & 77 & 23 & 0 & & \\
\hline 115.20 & 2.478 & 2.566 & 92 & 97 & 82 & 18 & 0 & 0.137 & 1.574 \\
\hline 115.60 & 2.479 & 2.568 & 76 & 98 & 84 & 16 & 0 & & \\
\hline 116.15 & 2.481 & 2.570 & 88 & 98 & 83 & 17 & 0 & & \\
\hline 116.75 & 2.484 & 2.572 & 93 & 98 & 87 & 13 & 0 & -0.295 & 1.273 \\
\hline 117.15 & 2.486 & 2.574 & 89 & 98 & 85 & 15 & 0 & & \\
\hline 117.68 & 2.488 & 2.576 & 89 & 98 & 85 & 15 & 0 & & \\
\hline 118.28 & 2.490 & 2.578 & 90 & 99 & 90 & 10 & 0 & 0.269 & 1.784 \\
\hline 118.68 & 2.492 & 2.580 & 91 & 97 & 85 & 15 & 0 & & \\
\hline 119.18 & 2.494 & 2.582 & 92 & 97 & 85 & 15 & 0 & & \\
\hline 119.78 & 2.496 & 2.584 & 88 & 97 & 90 & 10 & 0 & -0.400 & 1.297 \\
\hline 120.18 & 2.498 & 2.586 & 84 & 98 & 81 & 19 & 0 & & \\
\hline 120.68 & 2.500 & 2.588 & 82 & 97 & 76 & 24 & 0 & & \\
\hline 121.28 & 2.502 & 2.590 & 88 & 98 & 80 & 20 & 0 & 0.383 & 1.375 \\
\hline 121.68 & 2.504 & 2.592 & 72 & 98 & 80 & 20 & 0 & & \\
\hline 122.18 & 2.506 & 2.594 & 80 & 98 & 72 & 28 & 0 & & \\
\hline 122.55 & 2.508 & 2.595 & 93 & & & & & 0.393 & 1.455 \\
\hline 122.63 & 2.508 & 2.595 & 87 & 97 & 80 & 20 & 0 & & \\
\hline 123.15 & 2.510 & 2.598 & 93 & & & & & 0.173 & 1.208 \\
\hline 123.55 & 2.512 & 2.599 & 84 & 96 & 77 & 23 & 0 & & \\
\hline 124.05 & 2.514 & 2.601 & 60 & 96 & 85 & 15 & 0 & & \\
\hline 124.65 & 2.516 & 2.604 & 90 & 98 & 89 & 11 & 0 & 0.101 & 1.526 \\
\hline 125.05 & 2.518 & 2.606 & 69 & 97 & 85 & 15 & 0 & & \\
\hline 125.55 & 2.520 & 2.608 & 88 & 98 & 83 & 17 & 0 & & \\
\hline
\end{tabular}


APPENDIX (continued).

\begin{tabular}{|c|c|c|c|c|c|c|c|c|c|}
\hline $\begin{array}{l}\text { Depth } \\
\text { (mbsf) }\end{array}$ & $\begin{array}{c}\text { Biostrat. } \\
\text { Age (Ma) }\end{array}$ & $\begin{array}{c}\delta^{18} \mathrm{O}^{*} \\
\text { Age(Ma) }\end{array}$ & $\begin{array}{c}\text { Fine } \\
\text { fraction }(\%)\end{array}$ & $\begin{array}{c}\text { Fine } \\
\text { carbonate (\%) }\end{array}$ & $\begin{array}{c}\text { Fine } \\
\text { calcite (\%) }\end{array}$ & $\begin{array}{c}\text { Fine } \\
\text { aragonite (\%) }\end{array}$ & $\begin{array}{c}\text { Fin } \\
\text { dolomite (\%) }\end{array}$ & $\begin{array}{c}\delta^{18} \mathrm{O}_{\mathrm{PDB}} \\
\text { G. sacculifer }\left(\%_{0}\right)\end{array}$ & $\begin{array}{c}\delta^{3} \mathrm{C}_{\mathrm{PDB}} \\
\text { G. sacculifer }\left(\%_{0}\right)\end{array}$ \\
\hline 126.15 & 2.522 & 2.610 & 83 & 99 & 89 & 11 & 0 & -0.170 & 1.571 \\
\hline 126.55 & 2.524 & 2.612 & 61 & 97 & 86 & 14 & 0 & & \\
\hline 127.05 & 2.526 & 2.614 & 77 & 97 & 80 & 20 & 0 & & \\
\hline 127.65 & 2.528 & 2.617 & 90 & 98 & 91 & 9 & 0 & -0.281 & 1.537 \\
\hline 128.05 & 2.530 & 2.618 & 89 & 97 & 88 & 12 & 0 & & \\
\hline 128.55 & 2.532 & 2.620 & 82 & 97 & 90 & 10 & 0 & & \\
\hline 129.15 & 2.535 & 2.623 & 77 & 98 & 92 & 8 & 0 & -0.319 & 1.208 \\
\hline 129.55 & 2.536 & 2.625 & 83 & 97 & 86 & 14 & 0 & & \\
\hline 130.05 & 2.538 & 2.628 & 69 & 98 & 79 & 21 & 0 & & \\
\hline 130.65 & 2.541 & 2.631 & 90 & 98 & 72 & 28 & 0 & 0.233 & 1.667 \\
\hline 131.05 & 2.542 & 2.633 & 85 & 97 & 77 & 23 & 0 & & \\
\hline 131.55 & 2.544 & 2.635 & 83 & 97 & 79 & 21 & 0 & 0.034 & 1.345 \\
\hline 132.02 & 2.546 & 2.638 & 82 & 98 & 77 & 23 & 0 & & \\
\hline 132.65 & 2.549 & 2.641 & 86 & 98 & 82 & 18 & 0 & 0.147 & 1.607 \\
\hline 133.05 & 2.551 & 2.643 & 74 & 97 & 80 & 20 & 0 & & \\
\hline 133.52 & 2.552 & 2.646 & 85 & 97 & 83 & 17 & 0 & & \\
\hline 134.15 & 2.555 & 2.649 & 86 & 97 & 90 & 10 & 0 & 0.162 & 1.682 \\
\hline 134.55 & 2.557 & 2.651 & 88 & 97 & 86 & 14 & 0 & & \\
\hline 135.02 & 2.559 & 2.653 & 59 & 96 & 89 & 11 & 0 & & \\
\hline 135.65 & 2.561 & 2.657 & 85 & 98 & 89 & 11 & 0 & 0.336 & 1.599 \\
\hline 136.05 & 2.563 & 2.659 & 85 & 99 & 82 & 18 & 0 & & \\
\hline 136.52 & 2.565 & 2.661 & 84 & 98 & 81 & 19 & 0 & & \\
\hline 137.15 & 2.567 & 2.664 & 76 & 98 & 82 & 18 & 0 & 0.353 & 1.802 \\
\hline 137.55 & 2.569 & 2.667 & 89 & 98 & 80 & 20 & 0 & & \\
\hline 138.02 & 2.571 & 2.669 & 86 & 98 & 80 & 20 & 0 & & \\
\hline 138.65 & 2.573 & 2.672 & 84 & 98 & 83 & 17 & 0 & 0.314 & 1.810 \\
\hline 139.05 & 2.575 & 2.674 & 76 & 97 & & & & & \\
\hline 139.52 & 2.577 & 2.677 & 85 & 98 & 88 & 12 & 0 & & \\
\hline 140.15 & 2.580 & 2.680 & 91 & 97 & 87 & 13 & 0 & 0.199 & 1.711 \\
\hline 140.55 & 2.581 & 2.682 & 89 & 97 & 81 & 19 & 0 & & \\
\hline 141.02 & 2.583 & 2.684 & 80 & 97 & 78 & 22 & 0 & 0.545 & 1.675 \\
\hline 141.55 & 2.585 & 2.686 & 66 & 97 & 79 & 21 & 0 & & \\
\hline 142.15 & 2.588 & 2.689 & 66 & 97 & 77 & 22 & 1 & & \\
\hline 142.55 & 2.589 & 2.690 & 53 & 97 & 76 & 23 & 1 & & \\
\hline 143.05 & 2.591 & 2.692 & 72 & 97 & 75 & 24 & 1 & & \\
\hline 143.65 & 2.594 & 2.695 & 78 & 97 & 78 & 22 & 0 & 0.781 & 1.537 \\
\hline 144.01 & 2.595 & 2.697 & 75 & 96 & 77 & 23 & 1 & & \\
\hline 144.55 & 2.598 & 2.700 & 84 & 97 & 82 & 18 & 0 & & \\
\hline 145.15 & 2.600 & 2.703 & 82 & 97 & 83 & 17 & 0 & 0.465 & 1.448 \\
\hline 145.56 & 2.603 & 2.705 & 91 & 98 & 80 & 20 & 0 & & \\
\hline 146.05 & 2.606 & 2.707 & 88 & 98 & 80 & 20 & 0 & & \\
\hline 146.65 & 2.609 & 2.710 & 88 & 98 & 80 & 19 & 1 & 0.419 & 1.989 \\
\hline 147.06 & 2.612 & 2.712 & 86 & 98 & 84 & 15 & 0 & & \\
\hline 147.55 & 2.615 & 2.715 & 83 & 98 & 88 & 12 & 0 & & \\
\hline 148.15 & 2.619 & 2.718 & 89 & 97 & 93 & 7 & 0 & 0.058 & 1.757 \\
\hline 148.56 & 2.621 & 2.720 & 88 & 99 & 93 & 7 & 0 & & \\
\hline 149.05 & 2.624 & 2.722 & 86 & 98 & 88 & 12 & 0 & & \\
\hline 149.65 & 2.628 & 2.725 & 87 & 98 & 79 & 20 & 1 & 0.398 & 1.566 \\
\hline 150.06 & 2.631 & 2.727 & 84 & 99 & 78 & 21 & 1 & & \\
\hline 150.55 & 2.634 & 2.730 & 88 & 98 & 86 & 14 & 1 & & \\
\hline 151.05 & 2.637 & 2.732 & 93 & 98 & 83 & 14 & 3 & 0.499 & 1.643 \\
\hline 151.15 & 2.638 & 2.733 & 69 & 97 & 89 & 11 & 0 & & \\
\hline 151.65 & 2.641 & 2.735 & 87 & 97 & 82 & 18 & 1 & 0.211 & 1.627 \\
\hline 152.05 & 2.643 & 2.737 & 82 & 98 & 79 & 21 & 0 & & \\
\hline 152.55 & 2.646 & 2.740 & 68 & 97 & 88 & 11 & 1 & & \\
\hline 153.15 & 2.650 & 2.743 & 70 & 98 & 88 & 11 & 2 & 0.785 & 1.809 \\
\hline 153.55 & 2.653 & 2.745 & 84 & 97 & 84 & 15 & 1 & & \\
\hline 154.05 & 2.656 & 2.747 & 81 & 97 & 80 & 18 & 2 & & \\
\hline 154.65 & 2.659 & 2.750 & 55 & 97 & 85 & 12 & 2 & -0.026 & 1.232 \\
\hline 155.05 & 2.662 & 2.753 & 73 & 95 & 82 & 16 & 2 & & \\
\hline 155.55 & 2.665 & 2.757 & 88 & 95 & 85 & 14 & 1 & & \\
\hline 156.15 & 2.669 & 2.762 & 92 & 97 & 96 & 4 & 1 & 0.204 & 1.608 \\
\hline 156.55 & 2.671 & 2.765 & 92 & 97 & 89 & 10 & 1 & & \\
\hline 157.05 & 2.675 & 2.768 & 83 & 97 & 93 & 7 & 1 & & \\
\hline 157.65 & 2.678 & 2.773 & 91 & 97 & 85 & 14 & 1 & 0.943 & 1.645 \\
\hline 158.05 & 2.681 & 2.774 & 84 & 97 & 86 & 13 & 1 & & \\
\hline 158.55 & 2.684 & 2.776 & 67 & 93 & 85 & 15 & 0 & & \\
\hline 159.15 & 2.688 & 2.778 & 92 & 97 & 86 & 12 & 1 & 0.153 & 1.798 \\
\hline 159.55 & 2.690 & 2.780 & 81 & 98 & 82 & 18 & 1 & & \\
\hline 160.05 & 2.693 & 2.782 & 90 & 97 & 85 & 14 & 1 & 0.328 & 1.632 \\
\hline 160.55 & 2.696 & 2.783 & 78 & 97 & 86 & 14 & 0 & & \\
\hline 161.15 & 2.700 & 2.786 & 68 & 97 & 90 & 10 & 1 & 0.217 & 1.781 \\
\hline 161.54 & 2.703 & 2.787 & 85 & 98 & 85 & 15 & 0 & & \\
\hline 162.05 & 2.706 & 2.789 & 67 & 97 & 81 & 19 & 1 & & \\
\hline 162.65 & 2.710 & 2.791 & 83 & 97 & 75 & 24 & 1 & 0.171 & 1.623 \\
\hline 163.04 & 2.712 & 2.792 & 59 & 98 & 87 & 12 & 1 & & \\
\hline 163.55 & 2.715 & 2.794 & 75 & 97 & 81 & 19 & 1 & & \\
\hline 164.15 & 2.719 & 2.796 & 90 & 97 & 83 & 13 & 3 & 0.186 & 1.680 \\
\hline 164.54 & 2.721 & 2.798 & 78 & 95 & 83 & 16 & 2 & & \\
\hline 165.05 & 2.725 & 2.800 & 84 & 96 & 82 & 16 & 1 & & \\
\hline 165.65 & 2.728 & 2.802 & 96 & 98 & 87 & 9 & 3 & 0.309 & 1.696 \\
\hline 166.04 & 2.731 & 2.803 & 80 & 96 & 91 & 6 & 4 & & \\
\hline 166.55 & 2.734 & 2.805 & 90 & 96 & 89 & 9 & 1 & & \\
\hline 167.15 & 2.738 & 2.807 & 95 & 97 & 93 & 5 & 2 & 0.112 & 1.837 \\
\hline 167.54 & 2.740 & 2.808 & 88 & 97 & 93 & 7 & 1 & & \\
\hline
\end{tabular}


A.W. DROXLER ET AL.

APPENDIX (continued).

\begin{tabular}{|c|c|c|c|c|c|c|c|c|c|}
\hline $\begin{array}{l}\text { Depth } \\
\text { (mbsf) }\end{array}$ & $\begin{array}{l}\text { Biostrat. } \\
\text { Age (Ma) }\end{array}$ & $\begin{array}{c}\delta^{18} \mathrm{O}^{*} \\
\text { Age(Ma) }\end{array}$ & $\begin{array}{c}\text { Fine } \\
\text { fraction }(\%)\end{array}$ & $\begin{array}{c}\text { Fine } \\
\text { carbonate (\%) }\end{array}$ & $\begin{array}{c}\text { Fine } \\
\text { calcite (\%) }\end{array}$ & $\begin{array}{c}\text { Fine } \\
\text { aragonite (\%) }\end{array}$ & $\begin{array}{c}\text { Fin } \\
\text { dolomite (\%) }\end{array}$ & $\begin{array}{c}\delta^{18} \mathrm{O}_{\mathrm{PDB}} \\
\text { G. sacculifer }(\% 0)\end{array}$ & $\begin{array}{c}\delta^{3} \mathrm{C}_{\mathrm{PDB}} \\
\text { G. sacculifer (\%o) }\end{array}$ \\
\hline 168.11 & 2.744 & 2.811 & 82 & 96 & 94 & 5 & 1 & & \\
\hline 168.65 & 2.747 & 2.812 & 95 & 97 & 90 & 9 & 1 & 0.159 & 1.726 \\
\hline 169.04 & 2.750 & 2.814 & 69 & 97 & 89 & 10 & 2 & & \\
\hline 169.55 & 2.753 & 2.816 & 95 & 97 & 97 & 2 & 1 & 0.251 & 1.833 \\
\hline 170.05 & 2.756 & 2.817 & 81 & 96 & 86 & 13 & 0 & & \\
\hline 170.65 & 2.760 & 2.820 & 92 & 98 & 90 & 8 & 2 & 0.370 & 1.920 \\
\hline 171.05 & 2.762 & 2.821 & 83 & 98 & 93 & 7 & 1 & & \\
\hline 171.55 & 2.765 & 2.823 & 87 & & & & & & \\
\hline 172.15 & 2.769 & 2.825 & 93 & 98 & 86 & 12 & 1 & 0.422 & 1.951 \\
\hline 172.54 & 2.772 & 2.826 & 66 & 96 & 88 & 11 & 1 & & \\
\hline 173.05 & 2.775 & 2.827 & 88 & & & & & & \\
\hline 173.65 & 2.778 & 2.829 & 93 & 98 & 80 & 17 & 2 & 0.399 & 1.794 \\
\hline 174.05 & 2.781 & 2.830 & 75 & 96 & 88 & 11 & 2 & & \\
\hline 174.55 & 2.784 & 2.831 & 87 & 97 & 90 & 9 & 1 & & \\
\hline 175.15 & 2.788 & 2.833 & 95 & 98 & 92 & 7 & 1 & 0.281 & 1.622 \\
\hline 175.55 & 2.790 & 2.834 & 73 & 96 & 94 & 5 & 1 & & \\
\hline 176.01 & 2.793 & 2.835 & 81 & 97 & 90 & 9 & 1 & & \\
\hline 176.65 & 2.797 & 2.836 & 89 & 98 & 95 & 5 & 1 & 0.355 & 1.884 \\
\hline 177.05 & 2.800 & 2.837 & 76 & 98 & 86 & 14 & 0 & & \\
\hline 177.55 & 2.803 & 2.839 & 83 & 97 & 87 & 13 & 0 & & \\
\hline 178.15 & 2.807 & 2.840 & 94 & 98 & 90 & 9 & 1 & 0.143 & 1.765 \\
\hline 178.55 & 2.809 & 2.841 & 88 & 96 & 93 & 6 & 1 & & \\
\hline 179.05 & 2.812 & 2.842 & 38 & 98 & 98 & 0 & 2 & 0.582 & 1.777 \\
\hline 179.55 & 2.815 & 2.844 & 84 & 97 & 96 & 4 & 0 & & \\
\hline 180.15 & 2.819 & 2.845 & 90 & 98 & 93 & 7 & 0 & -0.221 & 1.456 \\
\hline 180.55 & 2.822 & 2.847 & 82 & 98 & 89 & 9 & 2 & & \\
\hline 181.05 & 2.825 & 2.850 & 81 & 98 & 89 & 11 & 0 & & \\
\hline 181.65 & 2.829 & 2.853 & 86 & 98 & 84 & 16 & 0 & 0.458 & 1.664 \\
\hline 182.05 & 2.831 & 2.855 & 71 & 98 & 78 & 21 & 1 & & \\
\hline 182.55 & 2.834 & 2.857 & 87 & 98 & 78 & 21 & 1 & & \\
\hline 183.15 & 2.838 & 2.860 & 87 & 98 & 99 & 0 & i & -0.156 & 1.584 \\
\hline 183.55 & 2.841 & 2.861 & 79 & 96 & 99 & 0 & i & & \\
\hline 184.05 & 2.844 & 2.863 & 81 & 96 & 91 & 9 & 0 & & \\
\hline 184.65 & 2.847 & 2.865 & 78 & 97 & 92 & 7 & 1 & 0.247 & 1.610 \\
\hline 185.05 & 2.850 & 2.867 & 80 & 97 & 90 & 10 & 0 & & \\
\hline 185.55 & 2.853 & 2.869 & 78 & 98 & 85 & 15 & 0 & & \\
\hline 186.15 & 2.857 & 2.871 & 93 & 98 & 85 & 15 & 0 & 0.058 & 1.362 \\
\hline 186.55 & 2.859 & 2.872 & 85 & 97 & 81 & 18 & 1 & & \\
\hline 187.05 & 2.862 & 2.874 & 48 & 98 & 88 & 11 & 1 & & \\
\hline 187.65 & 2.866 & 2.876 & 91 & 98 & 86 & 14 & 0 & 0.089 & 1.399 \\
\hline 188.05 & 2.869 & 2.878 & 75 & 98 & 89 & 11 & 0 & & \\
\hline 188.55 & 2.872 & 2.880 & 89 & 98 & 93 & 5 & 2 & & \\
\hline 189.05 & 2.875 & 2.881 & 60 & 97 & 90 & 9 & 0 & & \\
\hline 189.65 & 2.879 & 2.884 & 95 & 98 & 90 & 8 & 2 & & \\
\hline 190.05 & 2.881 & 2.885 & 50 & 99 & 84 & 16 & 0 & & \\
\hline 190.55 & 2.884 & 2.887 & 93 & 98 & 86 & 14 & 0 & & \\
\hline 191.15 & 2.888 & 2.889 & 95 & 98 & 100 & 0 & 0 & & \\
\hline 191.55 & 2.891 & 2.891 & 81 & 98 & 93 & 7 & 0 & & \\
\hline 192.05 & 2.894 & 2.892 & 92 & 97 & 85 & 14 & 0 & & \\
\hline 192.65 & 2.897 & 2.895 & 87 & 99 & 100 & 0 & 0 & -0.341 & 1.152 \\
\hline 193.05 & 2.900 & 2.896 & 82 & 98 & 97 & 3 & 0 & & \\
\hline 193.55 & 2.914 & 2.898 & 84 & 97 & 93 & 7 & 0 & & \\
\hline 194.15 & 2.930 & 2.900 & 93 & 98 & 100 & 0 & 0 & -1.107 & 1.072 \\
\hline 194.55 & 2.941 & 2.917 & 95 & 97 & 100 & 0 & 0 & & \\
\hline 195.05 & 2.955 & 2.938 & 73 & 98 & 100 & 0 & 0 & & \\
\hline 195.65 & 2.971 & 2.963 & 91 & 98 & 100 & 0 & 0 & -0.652 & 1.553 \\
\hline 196.05 & 2.982 & 2.979 & 77 & 97 & 100 & 0 & 0 & & \\
\hline 196.55 & 2.996 & 3.000 & 88 & 98 & 100 & 0 & 0 & & \\
\hline 197.15 & 3.012 & 3.025 & 91 & 98 & 100 & 0 & 0 & -0.203 & 1.387 \\
\hline 197.55 & 3.023 & 3.042 & 86 & 97 & 100 & 0 & 0 & & \\
\hline 198.05 & 3.037 & 3.063 & 67 & 97 & 100 & 0 & 0 & & \\
\hline 198.55 & 3.051 & 3.083 & 94 & 98 & 100 & 0 & 0 & -0.559 & 1.289 \\
\hline
\end{tabular}

*Age determined by visual correlation between the ${ }^{18} \mathrm{O}$ record for Hole $818 \mathrm{~B}$ and the ${ }^{18} \mathrm{O}$ record for Hole 806B from Jansen et al. (in press). 